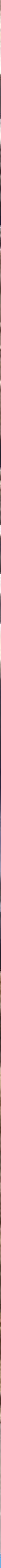

Energiebehoefte van droogstaande en lacterende guste Holstein Friesian koeien 



\section{Energiebehoefte van droogstaande en lacterende Holstein Friesian koeien}

J.W. Spek, L.B. Šebek

Dit onderzoek is onderdeel van het Publiek Private Samenwerking (PPS) project "Verbeteren van de Kringloopwijzer" (AF-17021) en ïs uitgevoerd door Wageningen Livestock Research, in opdracht van en gefinancierd door ZuivelNL en het Ministerie van Landbouw, Natuur en Voedselkwaliteit.

Wageningen Livestock Research

Wageningen, December 2019

Rapport 1211 
Spek, W.J. 2019. Energiebehoefte van droogstaande en lacterende Holstein Friesian koeien;

Wageningen Livestock Research, Rapport 1211.

Samenvatting NL

De Kringloopwijzer (KLW) is het belangrijkste rekeninstrument binnen de Nederlandse melkveehouderij om benutting van stikstof en fosfaat op individuele melkveebedrijven te monitoren. Het Nederlandse netto energiewaarderingssysteem voor herkauwers (het VEM systeem) wordt binnen de KLW gebruikt om te berekenen wat de voeropname is en bepaalt daarmee ook in belangrijke mate de excretie van fosfaat en stikstof in mest en de berekende opbrengst van weidegras. Uit recent metaanalyse onderzoek van data uit de Verenigde staten en het Verenigd Koninkrijk komt naar voren dat de huidige energiebehoefte voor onderhoud van melktypische melkgevende koeien fors hoger ( 30\%) ligt in vergelijking tot de huidige gehanteerde VEM normen voor onderhoud die zijn vastgesteld in 1975. Het doel van deze studie was om de energiebehoefte voor onderhoud en melkproductie van de moderne Holstein Friesian (HF) koe in Nederland vast te stellen. De in deze studie geschatte metaboliseerbare energiebehoefte voor onderhoud (MEond) bedroeg $566\left(\mathrm{KJ} / \mathrm{d} / \mathrm{kg} \mathrm{LG}{ }^{0.75}\right.$ ) voor de lacterende koeien en $614\left(\mathrm{KJ} / \mathrm{d} / \mathrm{kg} \mathrm{LG}^{0.75}\right)$ voor de droogstaande guste koeien. De efficiëntie waarmee metaboliseerbare energie werd omgezet in melkenergie was 0.634 . Beide geschatte $\mathrm{ME}_{\text {ond }}$ waarden liggen substantieel hoger dan de ME ond norm van het huidige VEM systeem van 488 (KJ/d/kg LG $\left.{ }^{0.75}\right)$. Op basis van deze studie wordt geconcludeerd dat de $\mathrm{ME}_{\text {ond }}$ voor droge en guste koeien hoger is dan voor lacterende koeien en dat de huidig aangehouden $\mathrm{ME}_{\text {ond }}$ behoefte voor niet drachtige melkkoeien in het VEM systeem te laag is voor de moderne HF melkkoe.

\section{Summary UK}

In the Netherlands the calculation tool "Annual Nutrient Cycling Assessment" abbreviated as "ANCA" is used by Dutch dairy farms as a tool to estimate the efficiency of dietary phosphorus and nitrogen utilization on farm level. In this tool the Dutch Net Energy system for dairy cattle, the so called VEM system, is used to calculate the feed intake of the cows and has an import role in calculating the utilization efficiency of dietary nitrogen and phosphorus. The present VEM system has been developed in 1975 and recent studies indicate that the energy requirement for maintenance in modern Holstein Friesian (HF) cows is around $30 \%$ higher than assumed in the VEM system. The goal of this study was to determine the energy requirements for maintenance and milk production for modern day HF cattle. Estimated metabolizable energy requirements for maintenance for dry and lactating dairy cattle were, respectively, 614 and $566 \mathrm{KJ} / \mathrm{d} / \mathrm{kg} \mathrm{BW} \mathrm{BW}^{0.75}$. The efficiency in which metabolizable energy was converted into milk energy was 0.634 . It is concluded that both the estimated metabolizable energy requirement for maintenance for dry non-pregnant cows and for lactating non-pregnant cows is substantially higher than the metabolizable energy requirement of $488 \mathrm{KJ} / \mathrm{d} / \mathrm{kg} \mathrm{BW} 0.75$ that is presently used in the Dutch VEM system.

Dit rapport is gratis te downloaden op https://doi.org/10.18174/506275 of op www.wur.nl/livestock-research (onder Wageningen Livestock Research publicaties).

(C) 2019 Wageningen Livestock Research

Postbus 338, 6700 AH Wageningen, T 03174839 53, E info.livestockresearch@wur.nl, www.wur.nl/livestock-research. Wageningen Livestock Research is onderdeel van Wageningen University \& Research.

Wageningen Livestock Research aanvaardt geen aansprakelijkheid voor eventuele schade voortvloeiend uit het gebruik van de resultaten van dit onderzoek of de toepassing van de adviezen.

Alle rechten voorbehouden. Niets uit deze uitgave mag worden vermenigvuldigd en/of openbaar gemaakt worden door middel van druk, fotokopie, microfilm of op welke wijze dan ook zonder voorafgaande toestemming van de uitgever of auteur.

Wageningen Livestock Research is NEN-EN-ISO 9001:2015 gecertificeerd. Op al onze onderzoeksopdrachten zijn de Algemene Voorwaarden van de Animal Sciences Group van toepassing. Deze zijn gedeponeerd bij de Arrondissementsrechtbank Zwolle. 


\section{Inhoudsopgave}

1.

Inleiding

2.

Materiaal en Methoden

10

2.1 Proefopzet en rantsoenen

2.2 Monstername en metingen

2.3 Chemische analyses

2.4 Berekeningen en statistiek

3.

\section{Resultaten}

3.1 Verloop van de proef

3.2 Melkproductie

3.3 Voeropname en verteerbaarheid

$\begin{array}{lll}3.4 & \text { Stikstof- en energiebalans } & 17\end{array}$

$\begin{array}{lll}3.5 & \text { Efficiëntie van de energieomzetting } & 18\end{array}$

$\begin{array}{lll}3.6 & \text { Energiebehoefte } & 20\end{array}$

4.

$\begin{array}{lll}4.1 & \text { Voeropname en verteerbaarheden } & 22\end{array}$

4.2 ME benutting voor melkproductie en energiebehoefte voor onderhoud 23

4.3 Energiemetabolisme $\quad 24$

4.4 Verschil tussen energie in mest en mest + urine 30

4.5 Verschil $\mathrm{ME}_{\text {ond }}$ tussen lacterende en droge koeien 31

5 


\section{Woord vooraf}

In het kader van het verbeteren van de Kringloopwijzer is de PPS AF-17021 "Verbeteren van de Kringloopwijzer" opgezet in samenwerking met ZuiveINL, Wageningen Livestock Research en Wageningen University. Binnen deze PPS wordt het Nederlandse netto energiesysteem voor herkauwers, het VEM systeem dat in de jaren 70 van de vorige eeuw is opgezet en geïntroduceerd, opnieuw geactualiseerd op basis van recente klimaatrespiratiegegevens met moderne Holstein Friesian melkkoeien. De gegevens uit deze proef waarin de energiebehoefte van droogstaande, laagproductieve en hoogproductieve lacterende niet drachtige Holstein Friesian koeien is gemeten zal in een vervolgstudie gecombineerd worden met eerder recent uitgevoerde klimaatrespiratieproeven om te komen tot een robuust geactualiseerd VEM systeem. De rekenregels van dit geactualiseerde VEM systeem zullen vervolgens geïntegreerd worden in de Kringloopwijzer.

Wouter Spek,

Projectleider. 


\section{Samenvatting}

De Kringloopwijzer (KLW) is het belangrijkste instrument binnen de Nederlandse melkveehouderij om benutting van stikstof en fosfaat op individuele melkveebedrijven te monitoren. Het Nederlandse netto energiewaarderingssysteem voor herkauwers (het VEM systeem) wordt binnen de KLW gebruikt om te berekenen wat de voeropname is en bepaalt daarmee ook in belangrijke mate de excretie van fosfaat en stikstof in mest en de berekende opbrengst van weidegras. Uit recent meta-analyse onderzoek uit de Verenigde Staten en het Verenigd Koninkrijk komt naar voren dat de huidige energiebehoefte voor onderhoud van melktypische melkgevende koeien fors hoger ( $30 \%)$ ligt in vergelijking tot de huidige gehanteerde VEM normen voor onderhoud die zijn vastgesteld in 1975 . Het doel van deze studie was om de energiebehoefte voor onderhoud en melkproductie van de moderne Holstein Friesian (HF) koe in Nederland vast te stellen. Er werden 24 koeien geselecteerd waarvan 12 hoogproductief en recent afgekalfd ( $45 \pm 3.5 \mathrm{~kg}$ melk, $81 \pm 8.7$ dagen in lactatie en een pariteit van $3.8 \pm 1.0$ ) en 12 laagproductief $(29 \pm 9.3 \mathrm{~kg}$ melk, $231 \pm 146.2$ dagen in lactatie en een pariteit van 3.0 \pm 1.5$)$ en gust. De helft van de hoogproductieve dieren kreeg een zetmeelrijk rantsoen (HP-ZET) en de andere helft van de hoogproductieve dieren kreeg een vezelrijk rantsoen (HP-VEZ). Hetzelfde was het geval voor de laagproductieve dieren waarvan de helft een zetmeelrijk rantsoen ontving (LP-ZET) en de andere helft een vezelrijk rantsoen (LP-VEZ). De melkgevende dieren, zowel hoog- als laagproductief, hadden een adaptatieperiode van 21 dagen op de standenstal gevolgd door één meetperiode in de klimaatrespiratiecellen (KRC) van 4 dagen. Echter, de laagproductieve dieren werden direct na de eerste meetperiode drooggezet en gedurende een periode van 17 dagen op hetzelfde voerniveau gehouden als tijdens de eerste meetperiode. Daarna volgde voor die dieren een tweede meetperiode van 4 dagen in de KRC om data gedurende de droogstand te genereren. De gemiddelde melkproductie voor de hoog- en laagproductieve dieren bedroeg respectievelijk 37.6 en $9.8 \mathrm{~kg} / \mathrm{d}$. Gemiddelde droge stofopname voor de hoog- en laagproductieve dieren bedroeg respectievelijk 22.1 en $10.8 \mathrm{~kg} / \mathrm{d}$. Gemiddeld lichaamsgewicht (LG; kg) van de koeien bedroeg respectievelijk 665 en 605 kg voor de hoog- en laagproductieve dieren. De in deze studie geschatte metaboliseerbare energiebehoefte voor onderhoud ( $\mathrm{ME}_{\text {ond }}$ ) bedroeg $566\left(\mathrm{KJ} / \mathrm{d} / \mathrm{kg} \mathrm{LG}^{0.75}\right.$ ) voor de lacterende koeien en $614\left(\mathrm{KJ} / \mathrm{d} / \mathrm{kg} \mathrm{LG}^{0.75}\right.$ ) voor de droogstaande koeien. De efficiëntie waarmee metaboliseerbare energie werd omgezet in melkenergie was 0.634 . Beide geschatte $\mathrm{ME}_{\text {ond }}$ waarden liggen substantieel hoger dan de $\mathrm{ME}_{\text {ond }}$ norm van het huidige VEM systeem van $488\left(\mathrm{KJ} / \mathrm{d} / \mathrm{kg} \mathrm{LG}{ }^{0.75}\right)$. Op basis van deze studie wordt geconcludeerd dat de $\mathrm{ME}_{\text {ond }}$ voor droge koeien $8 \%$ hoger is dan voor lacterende koeien en dat de huidig aangehouden $\mathrm{ME}_{\text {ond }}$ behoefte voor melkkoeien in het VEM systeem $14-21 \%$ te laag is voor de moderne HF melkkoe. 


\section{Summary}

In the Netherlands the calculation tool "Annual Nutrient Cycling Assessment" abbreviated as "ANCA" (Aarts et al, 2015) is used by Dutch dairy farmers as a tool to estimate the efficiency of dietary phosphorus and nitrogen utilization on dairy farms. In this tool the Dutch Net Energy system for dairy cattle, the so called VEM system is used to calculate the feed intake of the animals and has an import role in calculating the utilization efficiency of dietary nitrogen and phosphorus. The present VEM system has been developed in 1975 and recent studies indicate that the energy requirements for maintenance in modern Holstein Friesian (HF) cows is around 30\% higher than assumed in the VEM system. The goal of this study was to determine the energy requirements for maintenance and milk production for modern day HF cattle.

A number of 12 high producing ( $45 \pm 3.5 \mathrm{~kg}$ milk, $81 \pm 8.7$ days in milk, average parity of $3.8 \pm 1.0)$ and 12 non-pregnant low producing $(29 \pm 9.3 \mathrm{~kg}$ milk, $231 \pm 146.2$ days in milk, average parity of $3.0 \pm 1.5)$ HF cows were selected. Both high and low producing dairy cows were allocated to one of two diets, a high starch diet or a high fiber diet. Feed was offered ad libitum to high producing dairy cows and for the low producing dairy cows feed allowance was set to meet a milk production of $8 \mathrm{~kg}$ per day. After a 21 adaptation period cows were housed for 4 days in climate controlled respiration chambers in which energy and nitrogen metabolism was measured. After this $4 \mathrm{~d}$ measurement period the low producing cows ( $~ 10$ liter) were dried off and after a adaption period of 17 days followed a second measurement period of $4 \mathrm{~d}$ in the respiration chambers.

Average milk production of the high and low producing cows were, respectively, 37.6 and $9.8 \mathrm{~kg} / \mathrm{d}$. Average dry matter intake for the high and low producing cows were, respectively, 22.1 and 10.8 $\mathrm{kg} / \mathrm{d}$. Average body weight (BW; kg) of the cows were 665 and $605 \mathrm{~kg}$ for the high and low producing cows, respectively. Estimated metabolizable energy requirements for maintenance for dry and lactating dairy cattle were, respectively, 614 and $566 \mathrm{KJ} / \mathrm{d} / \mathrm{kg} \mathrm{BW}{ }^{0.75}$. The efficiency in which metabolizable energy was converted into milk energy was 0.634 . It is concluded that both the estimated metabolizable energy requirement for maintenance for dry non-pregnant cows and for lactating non-pregnant cows is substantially higher than the metabolizable energy requirement of 488 $\mathrm{KJ} / \mathrm{d} / \mathrm{kg} \mathrm{BW} \mathrm{B}^{0.75}$ that is presently used in the Dutch VEM system. 


\section{Inleiding}

De Kringloopwijzer (KLW) is het belangrijkste instrument binnen de melkveehouderij om excretie van stikstof en fosfaat te monitoren en te verminderen. Het Nederlandse netto energiewaarderingssysteem voor herkauwers (het VEM systeem) wordt binnen de KLW gebruikt om te berekenen wat de voeropname is en bepaalt daarmee ook in belangrijke mate de excretie van fosfaat en stikstof in mest en de berekende opbrengst van weidegras. Uit recent meta-analyse onderzoek met data uit de Verenigde Staten van Amerika (Moraes et al., 2015) en Groot Brittannië (Dong et al., 2015) van klimaatrespiratieonderzoek met melkgevende koeien komt naar voren dat de huidige onderhoudsbehoefte van melktypische melkgevende koeien fors hoger ( $30 \%)$ ligt in vergelijking tot de huidige gehanteerde CVB-energiebehoeftenormen voor onderhoud die zijn gebaseerd op werk van Van Es (1975). De onderzoeksgegevens suggereren ook dat de efficiëntie waarmee metaboliseerbare energie (ME) omgezet kan worden in melk is gestegen. Er is echter een grote onzekerheid in dit verhaal. De onderhoudsbehoefte is namelijk niet direct gemeten maar is berekend op basis van respiratieonderzoek met melkgevende dieren waarin de onderhoudsbehoefte is geschat als de interceptwaarde (van de $\mathrm{x}$-as) van de relatie tussen de Netto Energie voor lactatie ( $N E_{\mathrm{L}}, \mathrm{y}$-as) en $\mathrm{ME}$ opname via voer (x-as). De geschatte onderhoudsbehoefte bij een melkproductie van nul liter is dus een geëxtrapoleerde waarde. Het is onzeker of deze geschatte onderhoudsbehoefte ook geldig is voor droogstaande koeien. Literatuurgegevens suggereren dat, naarmate koeien minder productief zijn en minder voer opnemen, ook de onderhoudsbehoefte voor energie afneemt (Holter, 1974). Een te laag ingeschatte onderhoudsbehoeftenorm voor energie zal als gevolg hebben dat ook de berekende stikstof- en fosfaatexcreties en de gewasopbrengst op het melkveebedrijf te laag worden ingeschat. Het doel van deze studie was om de onderhoudsbehoefte van de moderne Holstein Friesian koe in Nederland vast te stellen. In deze proef werden twee type rantsoenen verstrekt, een zetmeelrijk rantsoen en een vezelrijk rantsoen. Zowel de vezelrijke als zetmeelrijke rantsoenen bevatten vezel- en zetmeelgehalten die ook in de Nederlandse praktijk gangbaar zijn. Er waren twee redenen voor het verstrekken van een vezelrijk en een zetmeelrijk rantsoen. Ten eerste om energiebehoeften te schatten die zowel gebruikt kunnen worden voor zetmeelrijke als vezelrijke rantsoenen. Ten tweede om de resultaten van deze proef te kunnen gebruiken in een vervolgstudie waarin ze als aanvulling gecombineerd worden met data van eerdere recent (2004 - 2018) uitgevoerde respiratieproeven met lacterende dieren. Variatie in rantsoenen t.o.v. verteerbare zetmeel-, vezel- en eiwitgehalten maakt het misschien mogelijk om specifieke metabole energiewaarden toe te kennen aan de (fecaal) verteerbare nutriënten zetmeel, NDF en eiwit. Dit maakt het mogelijk om de energiewaarde van voedermiddelen nauwkeuriger te kunnen inschatten.

In deze proef is het energiemetabolisme van hoogproductieve dieren, laagproductieve dieren en droogstaande guste dieren gemeten. Eerdere recent uitgevoerde respiratieproeven bevatten vooral gegevens van koeien met een gemiddelde melkproductie. Door in een vervolgstudie de gegevens van deze proef te combineren met data van eerder uitgevoerde respiratieproeven ontstaat een robuuste dataset met gegevens van droogstaande tot hoogproductieve dieren die gebruikt kan worden voor het afleiden van energiebehoeften voor onderhoud en voor melkproductie voor zowel laag- als hoogproductieve dieren. 


\section{Materiaal en Methoden}

\subsection{Proefopzet en rantsoenen}

De proef is goedgekeurd door de Instantie voor Dierenwelzijn (IVD) Wageningen en uitgevoerd in de periode oktober - december van 2018. Een 24 koeien werden geselecteerd waarvan 12 hoogproductief en recent afgekalfd $(45 \pm 3.5 \mathrm{~kg}$ melk, $81 \pm 8.7$ dagen in lactatie en een pariteit van $3.8 \pm 1.0)$ en 12 laagproductief en gust $(29 \pm 9.3 \mathrm{~kg}$ melk, $231 \pm 146.2$ dagen in lactatie en een pariteit

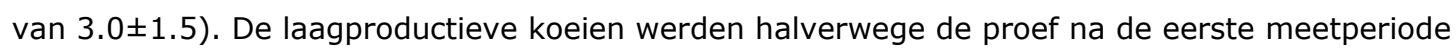
drooggezet. Na afloop van de proef zijn de laagproductieve dieren geslacht en werden orgaangewichten gemeten. Bij de dissectie bleken twee dieren toch drachtig te zijn waarbij één koe een totale vruchtmassa bij zich droeg van $8 \mathrm{~kg}$ (gewicht foetus was $1.4 \mathrm{~kg}$ ) en waarbij de vruchtmassa van de andere koe zeer gering was (gewicht niet gewogen, maar minder dan één kg). De helft van de hoogproductieve dieren kreeg een zetmeelrijk rantsoen (HP-ZET) en de andere helft van de hoogproductieve dieren kreeg een vezelrijk rantsoen (HP-VEZ). Hetzelfde was het geval voor de laagproductieve dieren waarvan de helft een zetmeelrijk rantsoen ontving (LP-ZET) en de andere helft een vezelrijk rantsoen (LP-VEZ). Alle rantsoenen werden gevoerd als een totaal gemengd rantsoen (TMR). De TMR rantsoenen bestonden uit een mengsel van een meelmengsel gemaakt door Research Diet Services (gevestigd in Wijk bij Duurstede) en een mengsel van kuilgras, maiskuil en gehakseld tarwestro. De geanalyseerde gemiddelde samenstelling van de ingrediënten (meelmengsels, maiskuil, kuilgras en tarwestro) zijn weergegeven in Tabel 1. De samenstelling van de TMR rantsoenen en de berekende chemische gehalten van de TMR rantsoenen zijn weergegeven in Tabel 2. 
Tabel 1 Ingrediëntsamenstelling van de meelmengsels en de geanalyseerde chemische gehalten van de meelmengsels, stro, maiskuil en kuilgras.

\begin{tabular}{|c|c|c|c|c|c|c|c|}
\hline \multicolumn{8}{|c|}{ Meelmengsels } \\
\hline & HP-VEZ & $\begin{array}{l}\text { HP- } \\
\text { ZET }\end{array}$ & $\begin{array}{l}\text { LP- } \\
\text { VEZ }\end{array}$ & $\begin{array}{l}\text { LP- } \\
\text { ZET }\end{array}$ & $\begin{array}{l}\text { Kuil } \\
\text { gras }\end{array}$ & $\begin{array}{r}\text { Mai } \\
\text { s } \\
\text { kuil }\end{array}$ & $\begin{array}{l}\text { Tarwe- } \\
\text { stro }\end{array}$ \\
\hline \multicolumn{8}{|l|}{ Ingrediënten ( $\mathrm{g} / \mathbf{k g}$ product) } \\
\hline Mais & 220 & 351 & 217 & 331 & & & \\
\hline Sojabonenhullen & 519 & 309 & 512 & 291 & & & \\
\hline Sojaschroot & 215 & 317 & 212 & 299 & & & \\
\hline RUMI-S & 23 & 4 & 22 & 4 & & & \\
\hline Plantaardig vet & 11.9 & 0.0 & 11.7 & 0.0 & & & \\
\hline Zout & 0.7 & 0.8 & 0.6 & 0.7 & & & \\
\hline Krijt & 0.0 & 3.8 & 0.0 & 3.6 & & & \\
\hline Ureum & 0.0 & 3.4 & 0.0 & 48.0 & & & \\
\hline Premix* & 8.0 & 7.9 & 7.9 & 7.5 & & & \\
\hline Titaniumdioxide & 3.4 & 3.8 & 17.2 & 15.4 & & & \\
\hline \multicolumn{8}{|c|}{ Geanalyseerde gehalten (g/kg DS) tenzij anders weergegeven } \\
\hline Droge stof & 885.2 & 887.6 & 887 & 886.9 & 589 & 336 & 931 \\
\hline Ruw as & 57 & 60 & 70 & 69 & 95 & 37 & 64 \\
\hline Organische stof & 943 & 940 & 930 & 931 & 905 & 963 & 936 \\
\hline Stikstof $(\mathrm{N}) * *$ & 32.6 & 39.2 & 32.0 & 58.9 & 26.9 & 11.3 & 5.2 \\
\hline Ruw eiwit $(\mathrm{RE})^{* *}$ & 204 & 245 & 200 & 368 & 168 & 74 & 33 \\
\hline $\mathrm{NH}_{3}-\mathrm{N}$ & & & & & 0.8 & 1.7 & \\
\hline Ruw vet (na zure hydrolyse) & 34 & 28 & 35 & 26 & 34 & 29 & 11 \\
\hline Zetmeel (amylase) & 167 & 248 & 167 & 222 & 10 & 362 & \\
\hline Reducerende suikers & 48 & 61 & 48 & 58 & 107 & 10 & 4 \\
\hline NDF & 367 & 265 & 356 & 257 & 508 & 344 & 793 \\
\hline ADF & 273 & 188 & 265 & 180 & 275 & 194 & 483 \\
\hline$A D L$ & 4 & 2 & 5 & 4 & 12 & 12 & 53 \\
\hline Ruwe celstof & 217 & 155 & 213 & 143 & 270 & 193 & 446 \\
\hline Bruto energie (MJ/kg DS) & 18.6 & 18.5 & 18.3 & 18.1 & 19.2 & 19.0 & 18.6 \\
\hline Titanium & 2.8 & 3.0 & 13.6 & 11.3 & 0.0 & 0.0 & 0.0 \\
\hline \multicolumn{8}{|l|}{ Berekende voederwaarden $* * *$} \\
\hline $\operatorname{VEM}(/ \mathrm{kg} D S)$ & 1133 & 1146 & 1115 & 1074 & 916 & 1006 & 425 \\
\hline DVE-07 (g/kg DS) & 134 & 152 & 132 & 142 & 67 & 54 & -5 \\
\hline OEB-07 (g/kg DS) & 17 & 45 & 17 & 189 & 40 & -43 & -18 \\
\hline VC-OS (\%) & 86.5 & 87.4 & 86.5 & 82.7 & 77.4 & 77.9 & 42.0 \\
\hline
\end{tabular}

* Samenstelling premix: Magnesiumoxide, $700 \mathrm{~g} / \mathrm{kg}$; Calciumcarbonaat, $260 \mathrm{~g} / \mathrm{kg}$; kopersulfaat, $2.500 \mathrm{~g} / \mathrm{kg}$; mangaanoxide, $3.750 \mathrm{~g} / \mathrm{kg}$, zinkoxide, $5.625 \mathrm{~g} / \mathrm{kg}$; calciumjodide, $0.187 \mathrm{~g} / \mathrm{kg}$; kobalt, 0.125 ; natriumseleniet, 0.0375 $\mathrm{g} / \mathrm{kg}$; a-Tocoferylacetaat, $0.625 \mathrm{~g} / \mathrm{kg}$; vitamine A, $1000000 \mathrm{IE}$; Vitamine D3, $187500 \mathrm{IE}$.

** RE en $\mathrm{N}$ gehalte gebaseerd op Kjeldahl analyse na vriesdrogen zonder correctie voor $\mathrm{NH}_{3}$. Dit $\mathrm{N}$ gehalte is ook gebruikt voor het berekenen van de $\mathrm{N}$ balans doordat is aangenomen dat bij vriesdrogen de $\mathrm{NH}_{3}$ stikstof in de ruwvoeders niet vervluchtigd.

*** Kuilgras en maiskuil zijn gebaseerd op Eurofins Agro analyses; meelmengsels en tarwestro zijn gebaseerd op CVB Tabelwaarden (2016). 
Tabel 2 Ingrediëntsamenstelling van de TMR rantsoenen en de chemische gehalten van de TMR rantsoenen gebaseerd op de geanalyseerde gehalten in de meelmengsels, het tarwestro, de maiskuil en het kuilgras*.

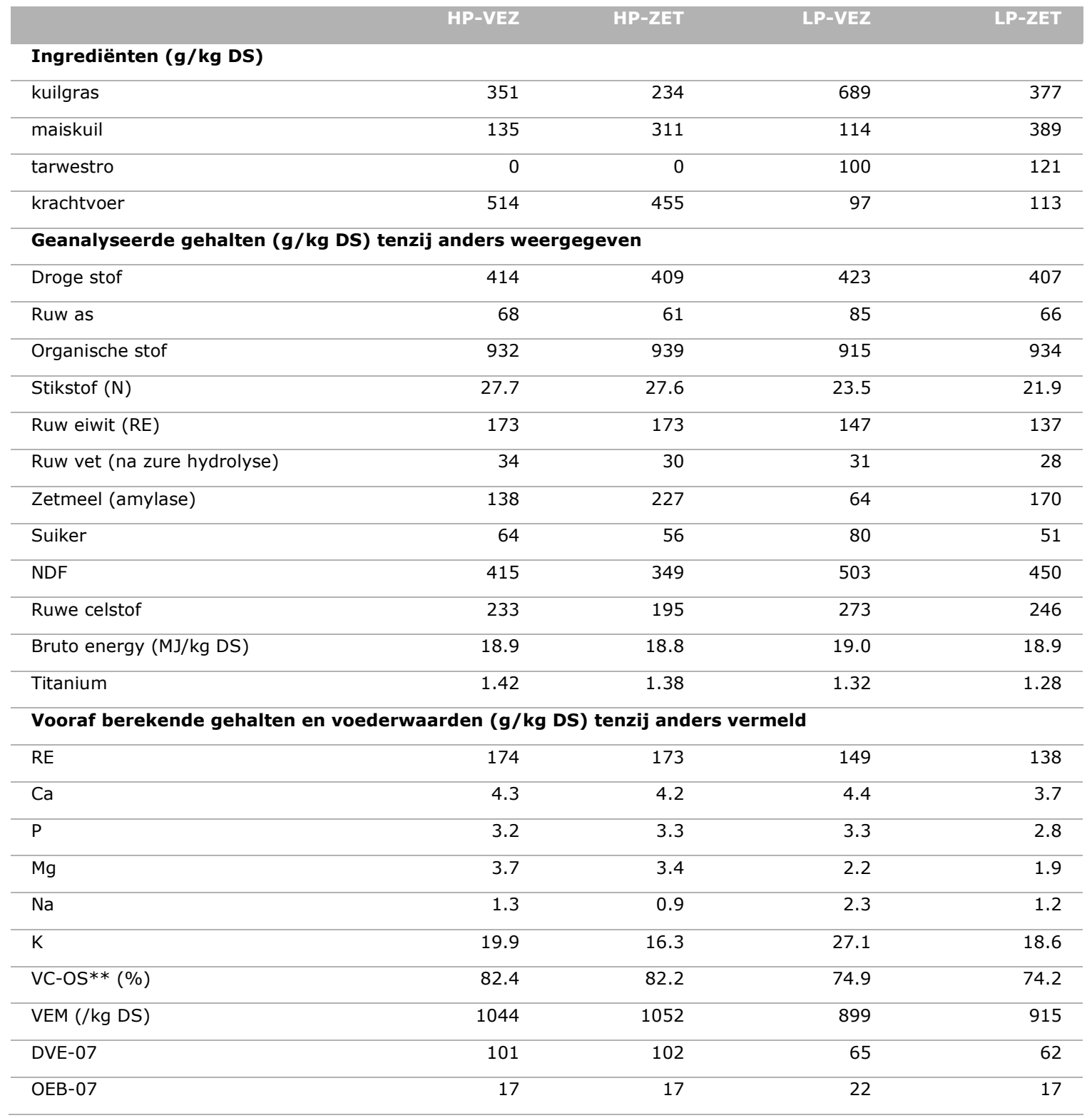

* Aan de rantsoenen werd water toegevoegd om te komen tot een DS gehalte van de TMR rantsoenen van $40 \%$.

** Schijnbare fecale verteringscoëfficiënt van de organische stof.

De hoogproductieve dieren hadden een adaptatieperiode van 21 dagen op de standenstal gevolgd door één meetperiode in de klimaatrespiratiecellen (KRC) van 4 dagen. De hoogproductieve dieren werden onbeperkt gevoerd. De laagproductieve dieren hadden een eerste adaptatieperiode van 21 dagen op de standenstal gevolgd door een eerste meetperiode in de KRC van 4 dagen. De dieren kregen gedurende de eerste adaptatieperiode een beperkte hoeveelheid voer van $10.4 \mathrm{~kg}$ DS per dag berekend voor een melkproductie van ongeveer $8 \mathrm{~kg}$ melk (gebruik makend van rekenregels in het CVB Tabellenboek Veevoeding Herkauwers (2016)). Direct na de eerste meetperiode werden de laagproductieve dieren verplaatst naar de standenstal, drooggezet (door te stoppen met melken), en op hetzelfde voerniveau gehouden als tijdens de eerste meetperiode gedurende een periode van 17 dagen (dit was de tweede adaptatieperiode) gevolgd door een tweede meetperiode van 4 dagen in de KRC. De laagproductieve dieren kregen gedurende de hele proef hetzelfde voer. Vanwege de beperkte capaciteit van de KRC (maximaal 6 dieren) was het noodzakelijk om de dieren trapsgewijs te laten beginnen aan de proef waarbij de hoogproductieve dieren het eerst begonnen aan de proef.

Twee keer per week werden de rantsoenen gemaakt, één keer per week voor 3 dagen en één keer per week voor vier dagen. Voor de 4-daagse meetperioden in de KRC werd één keer voer gemaakt. Direct na het maken van de rantsoenen werd het voer per voerbeurt per koe afgewogen in bakken (in kg, 2 
decimalen nauwkeurig), aangedrukt en gekoeld $\left(4^{\circ} \mathrm{C}\right.$ ) opgeslagen. Om broei te voorkomen werd het voer bestemd voor de laatste dag van de 4-daagse periode een nacht opgeslagen bij - $20{ }^{\circ} \mathrm{C}$ waarna het verder werd bewaard in de koeling bij $4{ }^{\circ} \mathrm{C}$. Hoogproductieve dieren werden twee keer per dag individueel gevoerd en gemolken (om 05:00 en 15:00 uur). Laagproductieve dieren werden twee keer per dag individueel gevoerd (om 05:00 en 15:00 uur) en één keer per dag gemolken (om 05:00 uur). Restvoer werd 's morgens direct voor het voeren teruggewogen (in kg, 2 decimalen nauwkeurig) voor het berekenen van de voeropname.

In de KRC werd de energie- en stikstofbalans bepaald d.m.v. het meten van 1) de totale droge stofopname, 2) het meten van de fecale verteerbaarheid d.m.v. het nemen van rectale mestmonsters, 3) het meten van uitstoot van energie en stikstof in mest en urine, 4) het meten van de consumptie van zuurstof en de productie van koolstofdioxide, methaan en ammoniak en 5) het meten van de melkproductie. Elke cel had een oppervlakte van $11.8 \mathrm{~m} 2$, een inhoud van $34.5 \mathrm{~m} 3$. De luchtvochtigheid, temperatuur en ventilatiesnelheid bedroeg respectievelijk $80 \%, 10{ }^{\circ} \mathrm{C}$ en 750 liter/min voor de hoog productieve koeien en $70 \%, 14{ }^{\circ} \mathrm{C}$ en 750 liter/min voor de laagproductieve koeien. Koeien gingen om 9:00 uur in de cellen op maandagochtend en verlieten de cellen om 9:00 uur op vrijdagochtend. Voor de metingen van de consumptie van zuurstof en de productie van koolstofdioxide en methaan zijn alleen de laatste 3 meetdagen meegenomen van dinsdag 8:00 uur 's morgens tot vrijdag 8:00 uur's morgens. Voor de energie- en stikstofopname, de uitstoot van energie en stikstof in mest, urine en melk is gerekend met de volledige periode dat koeien in de KRC hebben gestaan (namelijk van maandagmorgen 9:00 uur tot vrijdagmorgen 9:00 uur).

\subsection{Monstername en metingen}

Kuilgras- en maiskuilmonsters werden genomen tijdens het maken van de rantsoenen (twee keer per week) en apart opgeslagen. Daarnaast werd er van het tarwestro en de meelmengsels elke keer dat er voer gemaakt werd een klein monster genomen en samengevoegd met de monsters die eerder genomen werden bij het maken van de rantsoenen. Ook van de TMR rantsoenen werden na het maken van de rantsoenen monsters genomen. De ruwvoer- en TMR-monsters werden vervolgens bewaard bij $-20^{\circ} \mathrm{C}$. De tarwestro en de meelmengsels werden bewaard bij kamertemperatuur en nadat de proef was afgelopen bij $-20^{\circ} \mathrm{C}$.

Tijdens de meetperioden in de KRC werd het restvoer per koe na 24 uur gewogen en vervolgens opgeslagen bij $4{ }^{\circ} \mathrm{C}$. Het restvoer van dagen $1-4$ werd per koe samengevoegd, aan het eind van de meetperiode goed gemengd, bemonsterd en vervolgens opgeslagen bij $-20{ }^{\circ} \mathrm{C}$.

Melkproductie werd dagelijks gemeten. Gedurende de meetperioden in de KRC werd bij elke melking ( 8 melkingen voor de hoogproductieve koeien en 4 melkingen voor de laagproductieve koeien een melkmonster $(10 \mathrm{ml}$ ) genomen en opgestuurd voor analyse op vet, eiwit, lactose, ureum en celgetal. Daarnaast werd bij elke melking een proportioneel melkmonster genomen $(2.5 \mathrm{~g} / \mathrm{kg}$ melk en $10 \mathrm{~g} / \mathrm{kg}$ melk voor respectievelijk de hoog- en laagproductieve koeien) voor analyse op stikstof en energie en bewaard bij -20 ${ }^{\circ} \mathrm{C}$. De per koe geproduceerde totale hoeveelheid mest en urine van de 4-daagse KRC periode werd direct na de balansperiode gewogen, gemengd, bemonsterd en opgeslagen bij $-20{ }^{\circ} \mathrm{C}$. Tijdens de meetperioden in de KRC werden op de tijdstippen 05:00 en 15:00 uur rectale mestmonsters genomen ( 8 monsters in totaal per meetperiode, ongeveer $800 \mathrm{~g}$ per monstername). Deze monsterhoeveelheden werden gewogen en gepoold per koe per meetperiode. Ook werd de ammoniak emissie (afkomstig van de vervluchtiging van ureum uit urine tijdens de meetperiode) vastgelegd door uitgaande lucht te leiden door een $25 \%$ zwavelzuuroplossing. Ook werd condensvocht (afkomstig van de warmtewisselaar) verzameld. Zowel de zwavelzuuroplossing met daarin de vastgelegde ammoniak uit de lucht als het condensvocht werd na elke meetperiode per koe opgeslagen bij $-20{ }^{\circ} \mathrm{C}$ tot het moment dat het geanalyseerd werd op stikstof. Tijdens de adaptatieperiode van de droogstaande dieren is de schofthoogte gemeten, de borstomvang en de lichaamsconditie (score 1 van zeer mager tot score 5 zeer vet). Direct na de proef werden 10 van 12 droogstaande dieren naar het slachthuis gebracht en geslacht. Tijdens het slachten werden de volgende gewichten vastgelegd: het karkas, lege pens plus lege netmaag, lege boekmaag, lege dunne darm plus dikke darm, lever en uier. 


\subsection{Chemische analyses}

Verse kuilgrasmonsters en maiskuilmonsters (genomen tijdens het maken van voer voor de 8 meetperiodes in de KRC), mengmestmonsters (urine + mest) afkomstig van de KRC tijdens de meetperioden en de rectale mestmonsters werden gevriesdroogd gedurende een periode van 7 dagen. Daarnaast werden verse kuilgras-, maiskuil-, mengmest- en rectale mestmonsters geanalyseerd op droge stof d.m.v. luchtdrogen bij $103{ }^{\circ} \mathrm{C}$ (ISO, 6496) en werden verse kuilgras- en maiskuilmonsters geanalyseerd op ammoniak. De gevriesdroogde kuilgras-, maiskuil- mengmest- en rectale mestmonsters, de meelmengsels en het tarwestro werden tevens geanalyseerd op droge stof bij 103 ${ }^{\circ} \mathrm{C}$ (ISO, 6496), op ruw eiwit d.m.v. de Kjeldahl methode (ISO 5983, 2005), en op bruto energie bepaald via verbranding (ISO 9831, 1998). De gevriesdroogde kuilgras- en maiskuilmonsters, het tarwestro en de meelmengsels werden verder geanalyseerd op ruw as (ISO, 5984), ruw vet met zure hydrolyse (ISO, 6492, 1999) en zetmeel enzymatisch (ISO 15914, 2004) (met uitzondering van de mengmestmonsters en slechts voor 2 kuilgrasmonsters). Kuilgras-, maiskuil-, meelmengsel- en rectale mestmonsters werden tevens geanalyseerd op ruwe celstof (ISO 6865, 2000), reducerende suikers (Van Vuuren et al. 1993) (met uitzondering van de rectale mestmonsters en slechts voor 2 maiskuilmonsters en) en NDF (tevens zijn 4 mengmestmonsters op NDF geanalyseerd). De ruwvoermonsters en meelmengsels zijn tevens geanalyseerd op ADF, ADL en titanium (tevens zijn 4 mengmestmonsters op titanium geanalyseerd). De melkmonsters genomen gedurende de meetperioden in de KRC (10 ml monsters) werden geanalyseerd op vet, eiwit, lactose, ureum en celgetal d.m.v. middel-infrarood spectrometrie (ISO 9622; 2013; VVB, Doetinchem, Nederland). De proportionele melkmonsters genomen tijdens de meetperioden in de KRC werden geanalyseerd op bruto energy (ISO 9831, 1998) en stikstof via de Kjeldahl methode (ISO 5983, 2005).

\subsection{Berekeningen en statistiek}

Warmteproductie $(\mathrm{KJ} / \mathrm{d})$ in de $\mathrm{KRC}$ is berekend als:

Warmteproductie $(\mathrm{KJ} / \mathrm{d})=16.18 \times \mathrm{O}_{2}(\mathrm{~L} / \mathrm{d})+5.02 \times \mathrm{CO}_{2}(\mathrm{~L} / \mathrm{d})-2.17 \times \mathrm{CH}_{4}(\mathrm{~L} / \mathrm{d})$ (formule van Brouwer, 1965 in Gerrits et al. (2015)).

Fecale verteerbaarheden van nutriënten zijn berekend op basis van het verschil in de ratio tussen nutriënten en titanium in voer en in de mest. Voor het berekenen van de hoeveelheid energie en stikstof uitgescheiden in mest en urine is de hoeveelheid energie en stikstof in de fecale mestmonsters opgeteld bij de hoeveelheid energie en stikstof in de mengmest. Er is aangenomen dat de terugwinning van titanium in mengmest $100 \%$ was. Deze aanname is gecontroleerd en onderbouwd op basis van de resultaten van deze proef. De controle is uitgevoerd door bij 4 dieren de hoeveelheid titanium uitgescheiden in mengmest te vergelijken met de hoeveelheid titanium opgenomen via het voer.

De energieretentie/mobilisatie is berekend als: energie opname - energie in mest en urine - energie in methaan - energie in warmte - energie in melk.

Het volgende model is gebruikt om de energiebenutting van hoogproductieve en laagproductieve dieren (exclusief droogstaande dieren) te schatten:

Als er sprake was van een negatieve energiebalans:

$\mathrm{NE}_{\mathrm{L}}\left(\mathrm{KJ} / \mathrm{d} / \mathrm{kg} \mathrm{LG}{ }^{0.75}\right)=\mathrm{B}_{0}+\mathrm{B}_{1} \times \mathrm{ME}+\mathrm{B}_{3} \times \mathrm{Mob}$

Anders:

$N E_{L}\left(K J / d / k g L G^{0.75}\right)=B_{0}+B_{I} \times\left(M E-\left(\right.\right.$ Ret $\left.\left./ B_{2}\right)\right)$

Waarbij:

$\mathrm{NE}_{\mathrm{L}}=$ energieoutput in melk $\left(\mathrm{KJ} / \mathrm{d} / \mathrm{kg} \mathrm{LG}{ }^{0.75}\right)$

$\mathrm{LG}^{075}=$ metabool lichaamsgewicht = lichaamsgewicht $(\mathrm{LG})$ tot de macht 0.75

$\mathrm{ME}=$ opname van metaboliseerbare energie via het voer $\left(\mathrm{KJ} / \mathrm{d} / \mathrm{kg} \mathrm{LG}{ }^{0.75}\right)$

Ret $=$ energieretentie in het lichaam $\left(\mathrm{KJ} / \mathrm{d} / \mathrm{kg} \mathrm{LG}^{0.75}\right)$ 
Mob $=$ mobilisatie van lichaamsenergie $\left(\mathrm{KJ} / \mathrm{d} / \mathrm{kg} \mathrm{LG} \mathrm{G}^{0.75}\right)$

$B_{0}=$ de interceptwaarde en gelijk aan de geschatte netto energie behoefte voor onderhoud $x-1$

$\left(\mathrm{NE}_{\text {ond }}\left(\left(\mathrm{KJ} / \mathrm{d} / \mathrm{kg} \mathrm{LG} \mathrm{G}^{0.75}\right)\right.\right.$ ). De metaboliseerbare energiebehoefte voor onderhoud (ME ond $(\mathrm{KJ} / \mathrm{d} / \mathrm{kg}$

$\left.L G^{0.75}\right)$ ) kan berekend worden als $\mathrm{NE}_{\text {ond }} / \mathrm{B}_{1}$.

$B_{1}=$ de efficiëntie waarmee ME uit voer wordt omgezet in $N E_{L}$.

$B_{2}=$ de efficiëntie waarmee ME uit voer wordt omgezet in lichaamsenergie (voornamelijk vet)

$B_{3}=$ de efficiëntie waarmee lichaamsenergie (voornamelijk vet) wordt omgezet in $N E_{L}$

Omdat de dataset ontoereikend was om de regressiefactoren $B_{2}$ en $B_{3}$ te schatten is ervoor gekozen om daarvoor gepubliceerde waarden uit de studie van Moraes et al. (2015) te gebruiken waarbij $B_{2}=$ 0.70 en $B_{3}=0.89$. Uiteindelijk zijn in het model alleen de parameters $B_{0}$ en $B_{1}$ geschat.

De PROC NLIN procedure van SAS (9.4) is gebruikt voor het fitten van de modellen.

De MEond gebaseerd op droogstaande koeien is als volgt berekend:

$\mathrm{ME}_{\text {ond }}\left(\mathrm{KJ} / \mathrm{d} / \mathrm{kg} \mathrm{LG} \mathrm{G}^{0.75}\right)=\operatorname{ME}$ opname $\left(\mathrm{KJ} / \mathrm{d} / \mathrm{kg} \mathrm{LG} \mathrm{G}^{0.75}\right)-\operatorname{Ret}\left(\mathrm{KJ} / \mathrm{d} / \mathrm{kg} \mathrm{LG} \mathrm{G}^{0.75}\right) / \mathrm{B}_{2}$

Waarbij 0.70 de efficiëntiefactor is waarmee ME wordt vastgelegd in lichaamsreserves. Dit betekent dat 30\% van de hoeveelheid energie die gebruik wordt bij het vastleggen van ME uit voer in lichaamsreserves als warmte vrijkomt en dat $70 \%$ van ME uit voer wordt vastgelegd in lichaamsreserves. Wanneer teruggerekend wordt hoeveel warmte is geproduceerd bij een zekere hoeveelheid energie die is vastgelegd in lichaamsreserves betekent dit dat $43 \%$ (uitkomst van 0.3 / $0.7 * 100$ ) van Ret is vrijgekomen als warmte. Voor mobilisatie van energie uit lichaamsreserves hoefde in deze studie bij droogstaande dieren geen rekening gehouden te worden doordat alle dieren zich in een positieve energiebalans bevonden. 


\section{Resultaten}

\subsection{Verloop van de proef}

De proef is verlopen zoals gepland met een paar uitzonderingen. Zo lag de gemiddelde droge stofopname voor de hoogproductieve koeien tijdens de laatste 4 dagen van de adaptatieperiode op de standenstal substantieel hoger dan tijdens de meetperiode in de KRC $(2.7 \pm 2.00 \mathrm{~kg} / \mathrm{d} ; \mathrm{P}=0.042$ bij de HP-vezel behandeling en $3.1 \pm 2.48 \mathrm{~kg} / \mathrm{d} ; \mathrm{P}=0.056$ bij de HP-ZET behandeling). Verder werd één van de laagproductieve dieren salmonella positief getest tijdens de eerste adaptatieperiode. Dit dier is direct na de eerste meetperiode in de KRC vervangen door een ander dier (ook gust) om de kans op besmetting van andere dieren te minimaliseren. Daarnaast kreeg één laagproductief dier aan het begin van de tweede adaptatieperiode (na 6 adaptatiedagen) pootproblemen (mogelijk een botbreuk). $\mathrm{Na}$ consultatie met de dierenarts heeft de dierenarts dit dier geëuthanaseerd. Dit dier is direct vervangen door een ander laagproductief gust dier.

\subsection{Melkproductie}

In Tabel 3 zijn melkproductieresultaten weergegeven. Een tweezijdige T-test tussen behandelingen HP-vezel en HP-zetmeel gaf aan dat er geen significante verschillen zijn in melkproductie en melkgehalten tussen de twee behandelingen. Evenzo gaf een tweezijdige T-test tussen behandelingen LP-vezel en LP-zetmeel aan dat er geen significante verschillen waren in melkproductie en melkgehalten tussen de twee behandelingen.

Tabel 3 Melkproductie en gehalten van vet, eiwit, lactose, ureum en celgetal in melk tijdens de meetperioden in de klimaatrespiratiecellen (gemiddelden \pm standaarddeviaties).

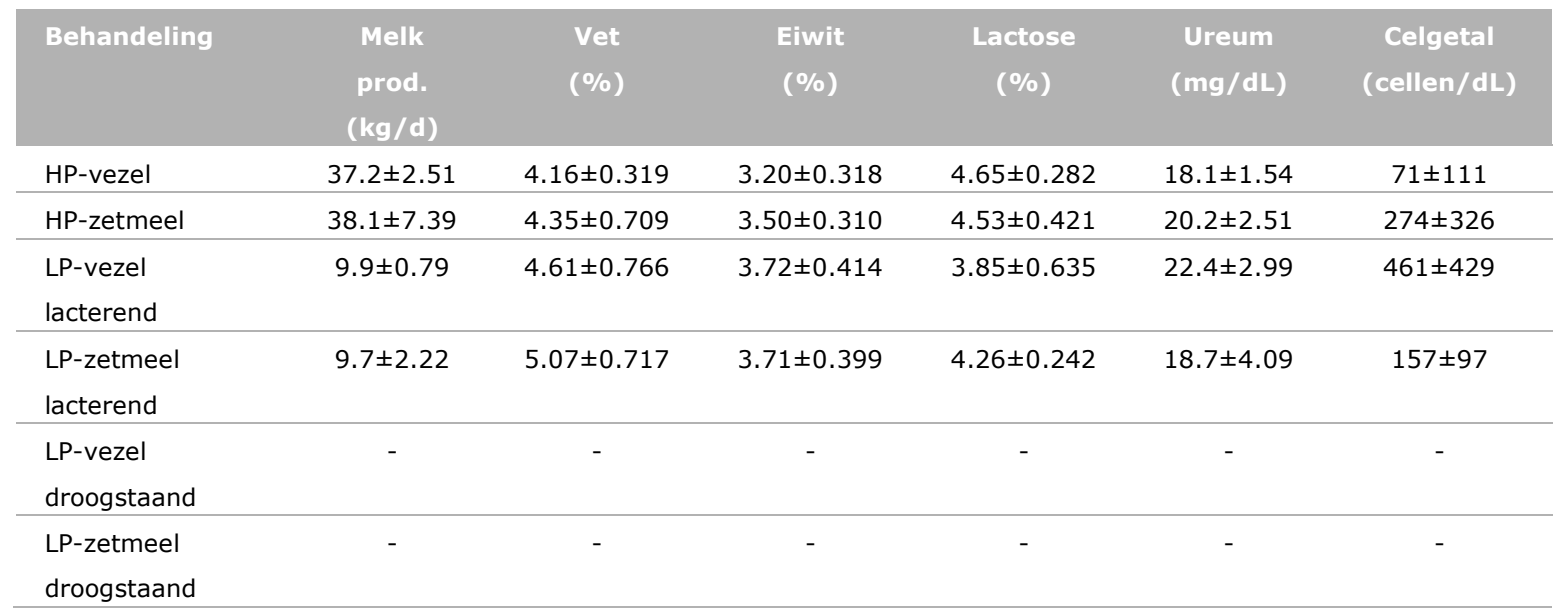

\subsection{Voeropname en verteerbaarheid}

In Tabel 4 zijn de voeropnames en de fecale verteerbaarheden van de nutriënten weergegeven voor de verschillende rantsoenen weergegeven. De LP-ZET en LP-VEZ rantsoenen verstrekt aan de laag producerende lacterende koeien en aan de droogstaande dieren waren hetzelfde. Wanneer de verschillen in droge stofopname en nutriëntverteerbaarheden tussen deze groepen werden vergeleken middels de niet gepaarde T-test bleek er alleen een significant verschil in ruw vet verteerbaarheid aanwezig te zijn tussen droogstaande en lacterende dieren bij het LP-ZET rantsoen. 
Tabel 4 Voeropname en fecale verteerbaarheden van nutriënten tijdens de meetperioden in de klimaatrespiratiecellen.

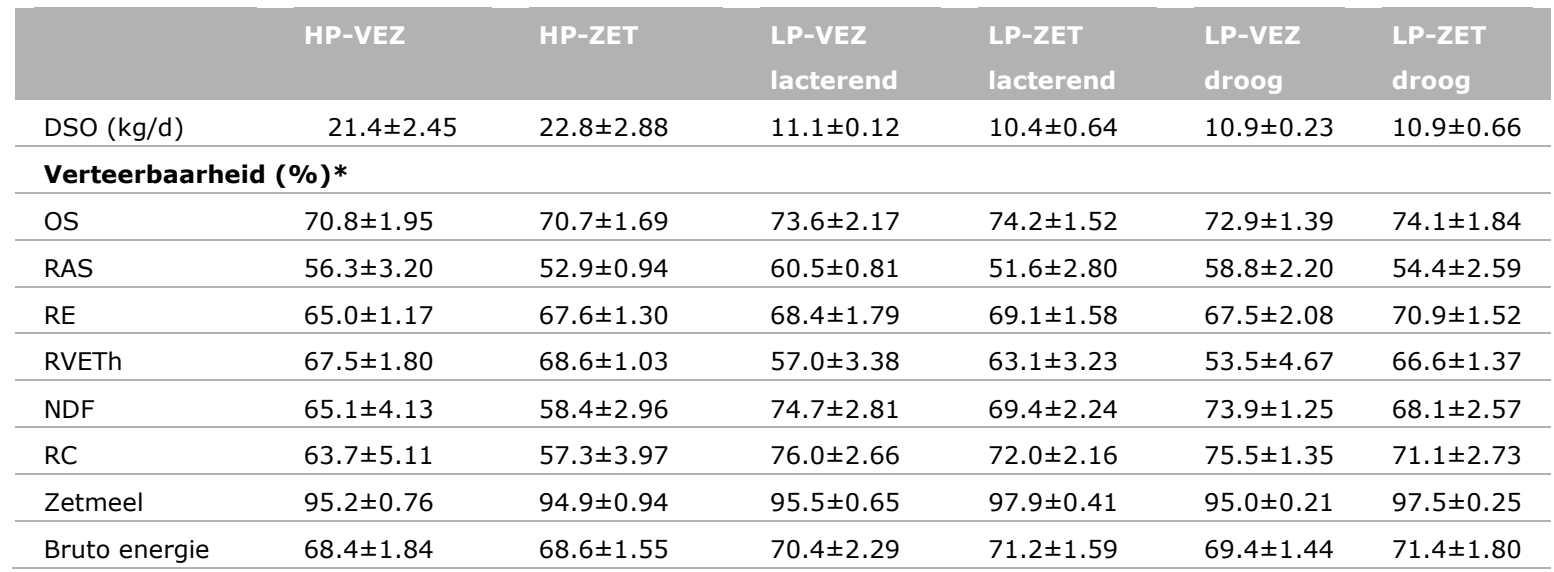

* DSO, droge stof opname; OS, organische stof; RAS, ruw as; RE, ruw eiwit; RVETh, ruw vet na zure hydrolyse; NDF, neutral detergent fibre; RC, ruwe celstof.

Voor het bepalen van de fecale verteerbaarheden van nutriënten zoals weergegeven in Tabel 4 is aangenomen dat titanium voor $100 \%$ onverteerbaar is. Deze aanname is bij 4 koeien getest waarbij de Ti terugwinning in mest is gemeten. Gemiddeld werd $99.2 \pm 2.1 \%$ van de Ti teruggevonden in de mest van de koeien.

\subsection{Stikstof- en energiebalans}

In Tabel 5 zijn de stikstof- en energiebalans gegevens afkomstig van de metingen uit de KRC weergegeven. Gemiddeld gezien hadden de hoogproductieve dieren een negatieve energiebalans, was de balans licht positief voor de LP-VEZ behandeling en licht negatief voor de LP-ZET behandeling. Alle droogstaande dieren hadden verder een positieve energiebalans. Alle behandelingen hadden een positieve stikstofbalans. 


\begin{tabular}{|c|c|c|c|c|c|c|}
\hline & HP-VEZ & HP-ZET & $\begin{array}{l}\text { LP-VEZ } \\
\text { lacterend }\end{array}$ & $\begin{array}{l}\text { LP-ZET } \\
\text { lacterend }\end{array}$ & $\begin{array}{l}\text { LP-VEZ } \\
\text { droog }\end{array}$ & $\begin{array}{l}\text { LP-ZET } \\
\text { droog }\end{array}$ \\
\hline \multicolumn{7}{|l|}{ Energie (kg LG ${ }^{0.75}$ ) } \\
\hline $\begin{array}{l}\text { Metabool gewicht } \\
\left(\mathrm{kg} \mathrm{LG}{ }^{0.75}\right)\end{array}$ & $130.4 \pm 12.82$ & $131.5 \pm 4.43$ & $124.6 \pm 14.29$ & $118.5 \pm 10.03$ & $127.3 \pm 14.55$ & $130.2 \pm 15.60$ \\
\hline $\begin{array}{l}\text { BE opname } \\
(\mathrm{kJ} / \mathrm{d} / \mathrm{kg} \mathrm{LG} 0.75 / \mathrm{d})\end{array}$ & $3128 \pm 529$ & $3265 \pm 398$ & $1717 \pm 220$ & $1677 \pm 165$ & $1653 \pm 220$ & $1595 \pm 206$ \\
\hline $\begin{array}{l}\text { Feces } \\
\left(\mathrm{kJ} / \mathrm{d} / \mathrm{kg} \mathrm{LG} \mathrm{L}^{0.75} / \mathrm{d}\right)\end{array}$ & $993 \pm 206$ & $1027 \pm 140$ & $508 \pm 72$ & $485 \pm 73$ & $508 \pm 46$ & $455 \pm 273$ \\
\hline $\begin{array}{l}\text { Urine } \\
\left(\mathrm{kJ} / \mathrm{d} / \mathrm{kg} \mathrm{LG} \mathrm{LG}^{0.75} / \mathrm{d}\right)^{*}\end{array}$ & $1 \pm 52$ & $66 \pm 22$ & $62 \pm 16$ & $80 \pm 21$ & $72 \pm 52$ & $99 \pm 27$ \\
\hline $\begin{array}{l}\text { Feces + urine } \\
\left(\mathrm{kJ} / \mathrm{d} / \mathrm{kg} \mathrm{LG} \mathrm{LG}^{0.75} / \mathrm{d}\right)\end{array}$ & $994 \pm 188$ & $1093 \pm 139$ & $570 \pm 79$ & $566 \pm 85$ & $580 \pm 141$ & $554 \pm 69$ \\
\hline $\begin{array}{l}\text { DE opname } \\
\left(\mathrm{kJ} / \mathrm{d} / \mathrm{kg} \mathrm{LG} \mathrm{L}^{0.75} / \mathrm{d}\right)\end{array}$ & $2135 \pm 330$ & $2238 \pm 273$ & $1208 \pm 163$ & $1192 \pm 94$ & $1145 \pm 132$ & $1140 \pm 165$ \\
\hline $\begin{array}{l}\text { Methaanproductie } \\
\left(\mathrm{kJ} / \mathrm{d} / \mathrm{kg} \mathrm{LG} \mathrm{LG}^{0.75} / \mathrm{d}\right)\end{array}$ & $205 \pm 28.4$ & $198 \pm 37.6$ & $132 \pm 14.3$ & $127 \pm 8.7$ & $127 \pm 16.2$ & $115 \pm 20.0$ \\
\hline $\begin{array}{l}\text { ME opname } \\
\left(\mathrm{kJ} / \mathrm{d} / \mathrm{kg} \mathrm{LG} \mathrm{L}^{0.75} / \mathrm{d}\right)\end{array}$ & $1929 \pm 320.1$ & $1974 \pm 265.8$ & $1015 \pm 140.3$ & $984 \pm 80.8$ & $946 \pm 76.8$ & $926 \pm 123.6$ \\
\hline $\mathrm{q}(100 \mathrm{ME} / \mathrm{BE})$ & $61.7 \pm 1.22$ & $60.4 \pm 1.58$ & $59.1 \pm 2.17$ & $58.8 \pm 1.71$ & $57.6 \pm 3.62$ & $58.0 \pm 1.35$ \\
\hline $\begin{array}{l}\text { Methaanproductie } \\
\text { (\% of } D E)\end{array}$ & $9.65 \pm 0.530$ & $8.87 \pm 1.379$ & $10.92 \pm 0.510$ & $10.72 \pm 0.645$ & $11.12 \pm 0.231$ & $10.09 \pm 0.587$ \\
\hline $\begin{array}{l}\text { Warmteproductie } \\
(\mathrm{kJ} / \mathrm{d} / \mathrm{kg} \mathrm{LG} 0.75 / \mathrm{d})\end{array}$ & $1075 \pm 99.9$ & $1097 \pm 72.1$ & $730 \pm 45.0$ & $713 \pm 52.8$ & $752 \pm 70.6$ & $757 \pm 47.3$ \\
\hline $\begin{array}{l}\text { Melk } \\
\left(\mathrm{kJ} / \mathrm{d} / \mathrm{kg} \mathrm{LG} \mathrm{L}^{0.75} / \mathrm{d}\right)\end{array}$ & $931 \pm 133.6$ & $966 \pm 149.9$ & $273 \pm 79.5$ & $293 \pm 67.5$ & - & - \\
\hline $\begin{array}{l}\text { Retentie } \\
\left(\mathrm{kJ} / \mathrm{d} / \mathrm{kg} \mathrm{LG} \mathrm{L}^{0.75} / \mathrm{d}\right)\end{array}$ & $-77 \pm 124.9$ & $-89 \pm 90.3$ & $12 \pm 67.8$ & $-22 \pm 75.4$ & $194 \pm 27.9$ & $169 \pm 94.0$ \\
\hline \multicolumn{7}{|l|}{ Stikstof (g/dag) } \\
\hline $\mathrm{N}$-opname & $593.4 \pm 69.88$ & $628.5 \pm 76.94$ & $261.1 \pm 3.27$ & $228.4 \pm 15.16$ & $255.2 \pm 2.66$ & $237.0 \pm 15.62$ \\
\hline $\mathrm{N}$ in feces+urine & $342.6 \pm 60.27$ & $386.0 \pm 39.98$ & $173.4 \pm 6.09$ & $158.0 \pm 16.58$ & $192.7 \pm 11.62$ & $175.9 \pm 7.31$ \\
\hline $\mathrm{N}$ in feces & $207.7 \pm 27.19$ & $203.6 \pm 25.80$ & $82.6 \pm 5.05$ & $70.5 \pm 5.29$ & $82.9 \pm 5.84$ & $69.1 \pm 6.39$ \\
\hline $\mathrm{N}$ in urine & $134.9 \pm 39.91$ & $182.4 \pm 18.53$ & $90.9 \pm 8.85$ & $87.5 \pm 14.67$ & $109.8 \pm 10.11$ & $106.8 \pm 3.76$ \\
\hline $\mathrm{N}$ in condensvocht & $5.2 \pm 1.22$ & $6.2 \pm 1.21$ & $3.73 \pm 1.69$ & $2.7 \pm 1.64$ & $4.3 \pm 0.69$ & $3.5 \pm 0.89$ \\
\hline $\mathrm{NH}_{3}-\mathrm{N}$ in lucht & $1.2 \pm 0.39$ & $1.4 \pm 0.65$ & $4.1 \pm 1.90$ & $3.8 \pm 2.26$ & $4.8 \pm 1.98$ & $5.1 \pm 2.05$ \\
\hline $\mathrm{N}$ in melk & $193.0 \pm 18.69$ & $214.7 \pm 34.10$ & $57.4 \pm 7.87$ & $55.5 \pm 8.80$ & - & - \\
\hline $\mathrm{N}$-retentie & $51.4 \pm 19.61$ & $20.2 \pm 11.51$ & $22.4 \pm 4.15$ & $8.4 \pm 5.37$ & $53.5 \pm 10.98$ & $52.5 \pm 10.77$ \\
\hline
\end{tabular}

* Berekend als Mest (kJ/d/kg LG $0.75 / d)$ - Feces (kJ/d/kg LG $0.75 / d)$.

\subsection{Efficiëntie van de energieomzetting}

In Tabel 6 zijn twee modellen weergegeven die zijn gebruikt voor het schatten van $E_{L}$. Model 1 is het model waarbij geen rekening wordt gehouden met mobilisatie en retentie van lichaamsenergie. In Model 2 is een model waarbij rekening wordt gehouden met mobilisatie en retentie van lichaamsenergie waarbij gebruik is gemaakt van schattingen voor retentie en mobilisatie van lichaamsenergie uit de studie van Moraes et al. (2015). De resultaten (Tabel 6) laten zien dat het corrigeren voor energieretentie en energiemobilisatie resulteert in een substantieel verbeterde model fit van $95.9 \%$ naar $98.6 \%$ en van een reductie van de RMSE van 74.2 naar 42.7 . 
Tabel 6 Geschatte modelparameters voor het schatten van de energie excretie in melk $((\mathrm{kJ} / \mathrm{d} / \mathrm{kg}$ $\left.L G^{0.75} / d\right)$.

\begin{tabular}{|c|c|c|c|c|c|c|}
\hline \multicolumn{7}{|c|}{ Modelparameters* } \\
\hline & Bo & $\mathbf{B}_{1}$ & B2 & B3 & RMSE & $\mathbf{R}^{2}$ \\
\hline Model 1 & $-356 \pm 45.7$ & $0.659 \pm 0.0292$ & - & - & 74.2 & 0.959 \\
\hline Model 2 & $-359 \pm 25.7$ & $0.634 \pm 0.0167$ & 0.70 & 0.89 & 42.7 & 0.986 \\
\hline
\end{tabular}

* De parameters B2 en B3 zijn niet door het model geschat maar als harde waarden ingevuld waarbij de waarden zijn gebaseerd op schattingen gepresenteerd in de studie van Moraes et al. (2015).

$B_{0}=$ de interceptwaarde en gelijk aan de geschatte netto energie behoefte voor onderhoud $\times-1\left(N E_{o n d}((K J / d / k g ~ L G 0.75))\right.$. De metaboliseerbare energiebehoefte voor onderhoud $\left(\mathrm{ME}_{\text {ond }}\left(\mathrm{KJ} / \mathrm{d} / \mathrm{kg} \mathrm{LG}{ }^{0.75}\right)\right.$ ) kan berekend worden als $\mathrm{B}_{0} / \mathrm{B}_{1}$.

$B_{1}=$ de efficiëntie waarmee ME uit voer wordt omgezet in melkenergie.

$B_{2}=$ de efficiëntie waarmee ME uit voer wordt omgezet in lichaamsenergie (voornamelijk vet)

$B_{3}=$ de efficiëntie waarmee lichaamsenergie (voornamelijk vet) wordt omgezet in melkenergie.

De relatie op basis van Model 2 in Tabel 6 is grafisch weergegeven in Figuur 1. In Figuur 1 zijn tevens de relaties voor de LP-behandelingen en HP-behandelingen apart weergegeven.

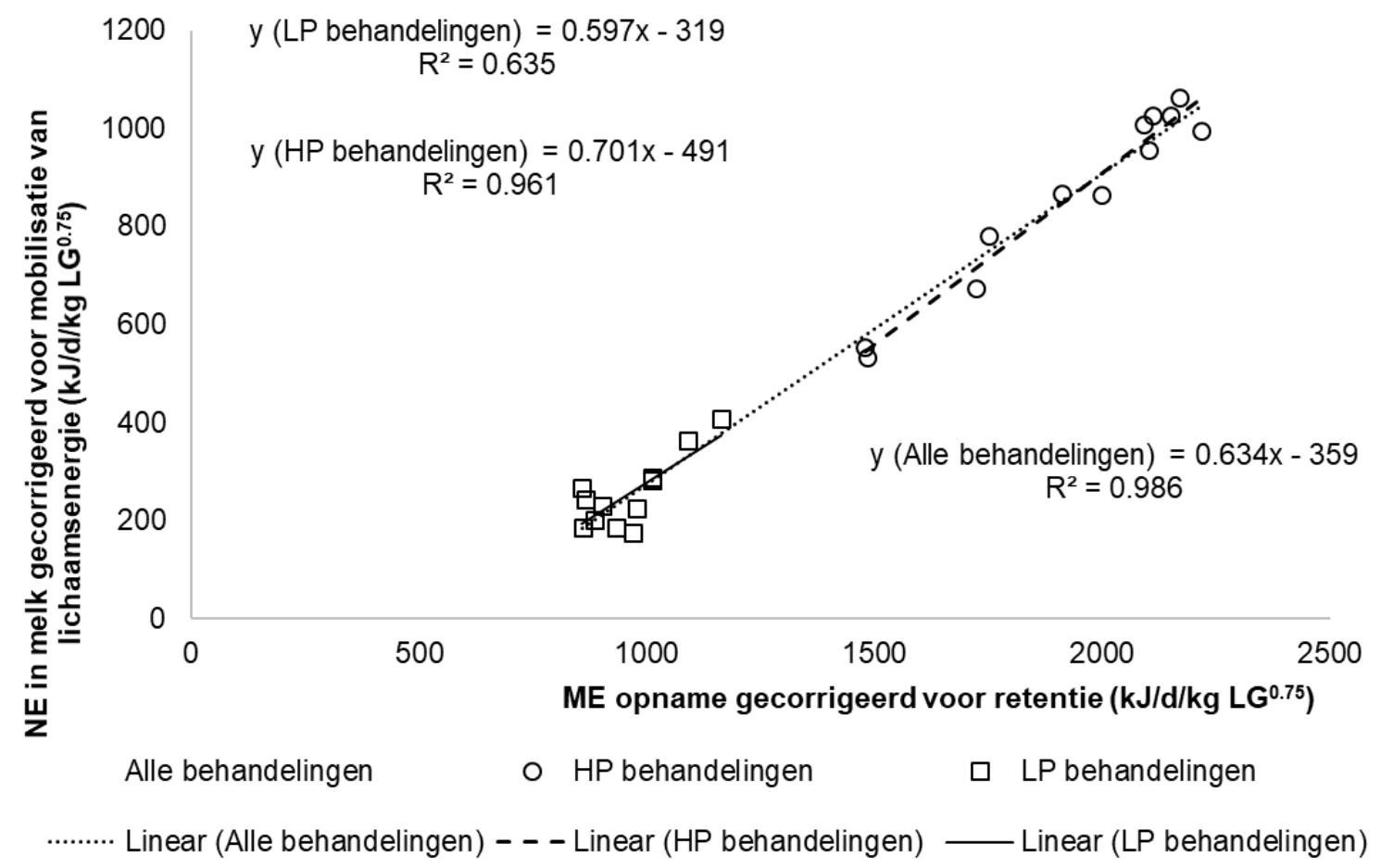

Figuur 1 Relatie tussen opname van metaboliseerbare energie gecorrigeerd voor retentie (ME opname; $K J / d / k g ~ L G^{0.75}$ ) en netto energie ( $N E ; K J / d / k g L G^{0.75}$ ) in melk gecorrigeerd voor mobilisatie van lichaamsenergie bij lacterende koeien (is grafische weergave van model 2 in Tabel 6). NE in melk gecorrigeerd voor alle behandelingen $\left(\mathrm{KJ} / \mathrm{d} / \mathrm{kg} \mathrm{LG}{ }^{0.75}\right)=$ $-359 \pm 25.7+0.634 \pm 0.0167 \times$ ME opname gecorrigeerd voor retentie $\left(\mathrm{KJ} / \mathrm{d} / \mathrm{kg} L \mathrm{G}^{0.75}\right)$; $R^{2}=0.986 ; R M S E=42.7$. 


\subsection{Energiebehoefte}

In Tabel 7 zijn de geschatte onderhoudsbehoeften weergegeven volgens:

1. De huidige CVB normen gebaseerd op resultaten van Van Es (1975)

2. De geschatte onderhoudsbehoeften voor lacterende koeien gebaseerd op de dataset met lacterende koeien in deze studie

3. De geschatte onderhoudsbehoeftenormen voor droogstaande dieren gebaseerd op de dataset met droogstaande dieren in deze studie

Tabel 7 De geëxtrapoleerde energiebehoefte voor onderhoud op basis van de lacterende koegegevens en de energiebehoefte voor onderhoud vastgesteld bij de droogstaande dieren waarbij is gecorrigeerd voor energieretentie en energiemobilisatie van lichaamsreserves en waarbij is aangenomen dat $B_{2}=0.70$ en $B_{3}=0.89$ (overgenomen uit resultaten van studie van Moraes et al. (2015).

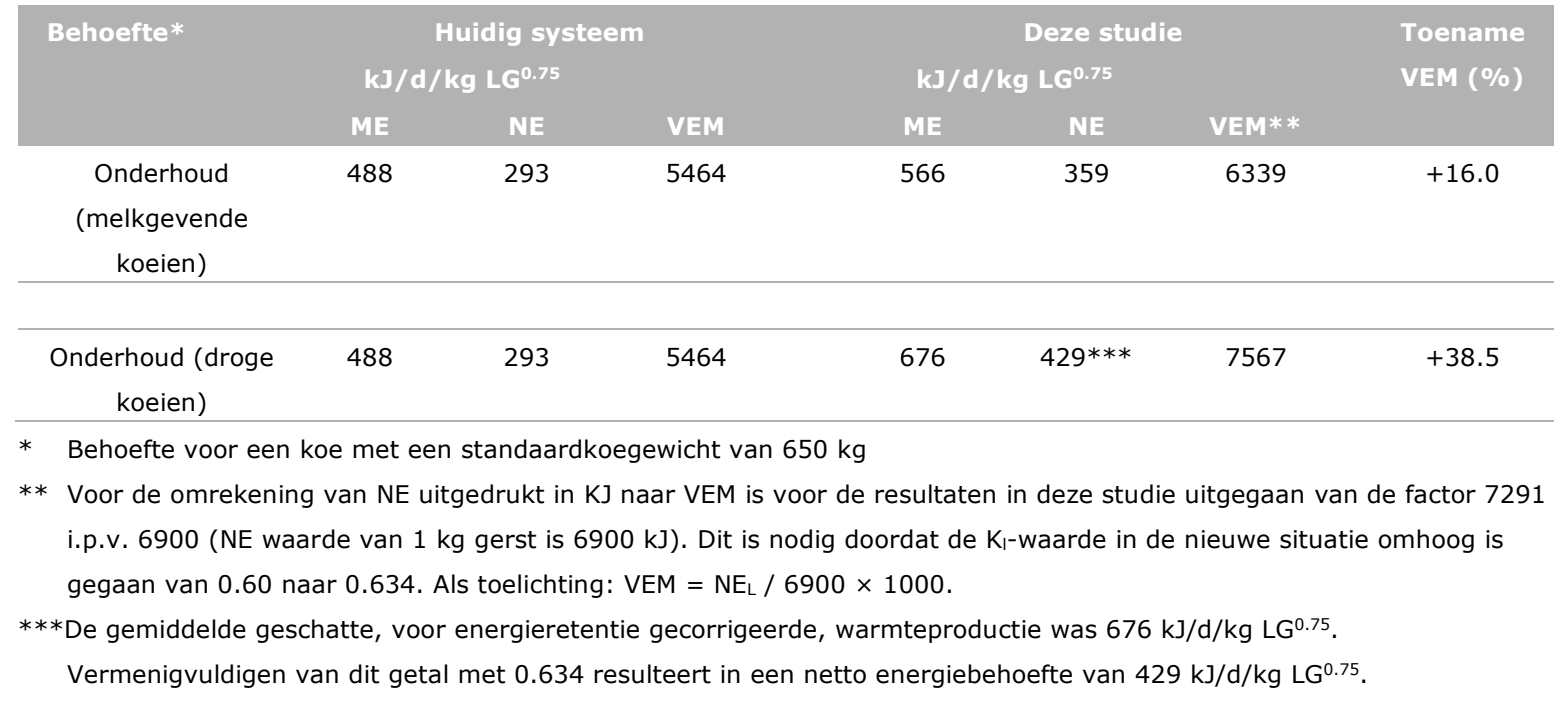

Resultaten uit Tabel 7 laten zien dat de netto energiebehoefte voor onderhoud zoals geschat in deze studie op de dataset van melkgevende koeien $16 \%$ hoger ligt dan de netto energiebehoefte van het huidige VEM systeem. Verder blijkt uit Tabel 7 dat de netto energiebehoefte voor onderhoud zoals geschat in deze studie op de dataset van droogstaande koeien $38 \%$ hoger ligt dan de netto energiebehoefte van het huidige VEM systeem.

In Tabel 8 zijn de correlaties weergegeven tussen de gemeten energiebehoefte voor onderhoud van droogstaande melkkoeien en de lichaamskenmerken van dezelfde koeien. Van alle droogstaande dieren $(n=12)$ is het energiemetabolisme gemeten en bepaalde lichaamskenmerken bepaald zoals gewicht, schofthoogte, borstomvang en BCS. Van deze 12 dieren zijn 10 dieren direct na de proef geslacht. Van deze dieren zijn ook de orgaan- en karkasgewichten bepaald. Dit verklaart het verschil tussen de aantallen 12 en 10 in tabel 8. Gebaseerd op de resultaten van dataset met 12 koeien is er een tendens van een negatieve correlatie tussen $M E_{\text {ond }}$ en levend gewicht $(P=0.072)$, tussen $M E_{\text {ond }}$ en metabool gewicht $(P=0.071)$ en tussen $M E_{\text {ond }}$ en levend gewicht : schofthoogte ratio $(P=0.065)$.

Gebaseerd op de dataset met 10 koeien werden er significante negatieve correlaties gemeten tussen $M E_{\text {ond }}$ en levend gewicht $(P=0.042)$, tussen $M E_{\text {ond }}$ en metabool gewicht $(P=0.042)$ en tussen $M E_{\text {ond }}$ en levend gewicht : schofthoogte ratio $(P=0.041)$. De correlaties tussen $M E_{\text {ond }}$ en slachtkenmerken zoals karkasgewicht, orgaangewichten, gepoolde orgaangewichten of ratio's tussen organen en levend gewicht bleken niet significant te zijn. 
Tabel 8 Pearson correlaties tussen energiebehoefte voor onderhoud en lichaamskenmerken van koeien droogstaande dieren.

\begin{tabular}{|c|c|c|c|c|c|}
\hline Parameters & $\mathbf{N *}$ & Gemiddelde & Stdev & r & $\mathbf{P}$ \\
\hline Levend gewicht (LG; kg) & 12 & 652 & 97.0 & -0.536 & 0.072 \\
\hline Metabool gewicht $\left(\mathrm{LG}^{0.75} ; \mathrm{kg}\right)$ & 12 & 129 & 14.5 & -0.539 & 0.071 \\
\hline Schofthoogte $(\mathrm{cm})$ & 12 & 144 & 5.6 & -0.292 & 0.357 \\
\hline Levend gewicht : schofthoogte & 12 & 4.5 & 0.58 & -0.548 & 0.065 \\
\hline Energiebehoefte onderhoud (KJ/d/kg LG $\left.{ }^{0.75}\right)$ & 10 & 677 & 63.4 & 1.00 & \\
\hline Levend gewicht (LG; kg) & 10 & 627 & 85.7 & -0.650 & 0.042 \\
\hline Metabool gewicht $\left(\mathrm{LG}^{0.75} ; \mathrm{kg}\right)$ & 10 & 125 & 12.9 & -0.649 & 0.042 \\
\hline Boekmaag (kg) & 10 & 7.1 & 1.35 & -0.539 & 0.108 \\
\hline Lebmaag (kg) & 10 & 3.3 & 0.57 & -0.595 & 0.070 \\
\hline Dunne + dikke darm $(\mathrm{kg})$ & 10 & 13.1 & 2.69 & -0.303 & 0.395 \\
\hline Lever (kg) & 10 & 9.1 & 1.06 & -0.493 & 0.148 \\
\hline Uier $(\mathrm{kg})$ & 10 & 18.0 & 5.77 & -0.267 & 0.457 \\
\hline Karkas : levend gewicht ratio (\%) & 10 & 48.2 & 2.24 & -0.346 & 0.327 \\
\hline Maag-darmpakket : levend gewicht ratio (\%) & 10 & 5.8 & 0.66 & 0.153 & 0.674 \\
\hline Som organen : levend gewicht ratio (\%) & 10 & 10.1 & 1.20 & 0.067 & 0.854 \\
\hline
\end{tabular}

* Van 12 dieren is het energiemetabolisme gemeten en bepaalde lichaamskenmerken. Van deze 12 dieren zijn 10 dieren direct na de proef geslacht. Dit verklaart het verschil tussen de aantallen 12 en 10 in deze tabel. 


\section{Discussie}

De proef is goed verlopen en volgens planning met uitzondering van het feit dat 1) twee dieren van de LP behandeling voortijdig de proef moesten verlaten, één dier vanwege een positieve test op Salmonella en één dier vanwege een gebroken poot en 2) dat de droge stofopname bij de HP behandelingen tijdens de laatste 4 dagen van de adaptatieperiode gemiddeld $3 \mathrm{~kg}$ hoger lag dan de voeropname tijdens de meetperiode erna in de KRC.

\subsection{Voeropname en verteerbaarheden}

In eerder uitgevoerde KRC proeven waarin dieren beperkt werden gevoerd bleek de voeropname tijdens de adaptatieperiode op de standenstal en de voeropname in de KRC niet van elkaar af te wijken. In deze proef is onbeperkt gevoerd en bleek er wel sprake van een verschil in voeropname. Wat het effect is geweest van een lagere voeropname tijdens de meetperiode in de KRC op de gemeten uitkomsten is niet vast te stellen.

De koeien die de LP behandelingen kregen werden beperkt gevoerd en hadden dezelfde voeropname tijdens zowel de adaptatie- als meetperiode. Een aantal van de dieren die de LP behandelingen kregen hadden het voer binnen 4 uur na verstrekking van het rantsoen al volledig opgegeten.

Resultaten in Tabel 4 laten zien dat de gemeten VC-OS waarden van de HP behandelingen duidelijk lager liggen dan die van de LP-behandeling. Dit komt niet overeen met de voorspelde schijnbare fecale VC-OS (Tabel 2), die zijn gebaseerd op onderzoek met hamels gevoerd op onderhoudsniveau. De vergelijking gaat mank doordat er geen rekening is gehouden met het voerniveau. In de publicatie van Van Es (1975) waarin het VEM systeem wordt toegelicht, wordt rekening gehouden met een verteringsdepressie van 3\% in energieverteerbaarheid per toename van het voerniveau (gebaseerd op werk van Hoffmann et al 1974). In het VEM-systeem is de onderhoudsbehoefte 5464 VEM/dag en op basis daarvan was het gemiddelde gerealiseerde voerniveau (M) in de huidige studie voor HP lacterend $=4,0 \mathrm{M}$, voor LP lacterend $=1,8 \mathrm{M}$ en voor $\mathrm{LP}$ droog $=1,8 \mathrm{M}$. Op basis van de uitgangspunten van het VEM systeem zou het effect van voeropname een voorspelde absolute verlaging van de VC-OS voor HP $=9.0 \%$ en voor $\mathrm{LP}=2.4 \%$ zijn. Deze voorspelde verlaging komt redelijk overeen met het in deze studie gevonden absolute verschil tussen voorspelde VC-OS en gemeten VC-OS voor HP $=11.6 \%$ en voor LP $=0,8 \%$ en passen binnen de daarover beschikbare literatuur. Echter, de literatuur maakt ook duidelijk dat er tussen studies substantiële verschillen bestaan m.b.t. het effect van voeropnameniveau op vertering. Zo rapporteerden Shaver et al. (1986) een vergelijkbare verteringsdepressie als welke in deze studie is berekend en rapporteerden Coluccie et al. (1982) een geringere verteringsdepressie. In de studie van Shaver et al. werd een combinatie van luzernehooi (60\%) en graan (40\%) gevoerd op 3 verschillende DSO niveaus (14.5, 20.2 en 24.3 kg DSO) waarbij VC-OS waarden van respectievelijk 70.1, 65.5 en 62.2\% gevonden werden (absoluut verschil in VC-OS van $7.9 \%$ tussen hoogste en laagste voeropname). In de studie van Colucci et al. (1982) werd een hoog krachtvoer- en een laag krachtvoerrantsoen aan zowel droge koeien als melkgevende koeien gevoerd. De DSO van de droogstaande dieren was 7.4 en $9.3 \mathrm{~kg}$ voor respectievelijk het hoge krachtvoer- en lage krachtvoerrantsoen en bij de melkgevende dieren was de DSO 23.9 en 19.5 voor het hoge krachtvoer- en lage krachtvoerrantsoen. De fecale verteerbaarheid van de droge stof bij de droogstaande dieren was 74.7 en $68.6 \mathrm{~kg}$ voor respectievelijk het hoge krachtvoer- en lage krachtvoerrantsoen en bij de melkgevende dieren was de fecale verteerbaarheid van de droge stof 68.4 en 65.4 voor het hoge krachtvoer- en lage krachtvoerrantsoen. Van Es (1975) gaf aan dat een verteringsdepressie groter wordt naarmate het aandeel krachtvoer in het rantsoen stijgt. In CVB verband wordt op dit moment gewerkt aan het updaten/valideren van het DVE systeem. Hiervoor is een grote dataset met darmdoorstromingsproeven opgebouwd. Uit een vergelijking tussen voorspelde VC-OS waarden (op basis van hamels) en gemeten VC-OS waarden in de door CVB gebruikte dataset blijkt ook dat een verteringsdepressie als gevolg van voeropname groter wordt naarmate het aandeel krachtvoer in het rantsoen toeneemt (Figuur 2). Het effect van krachtvoer op 


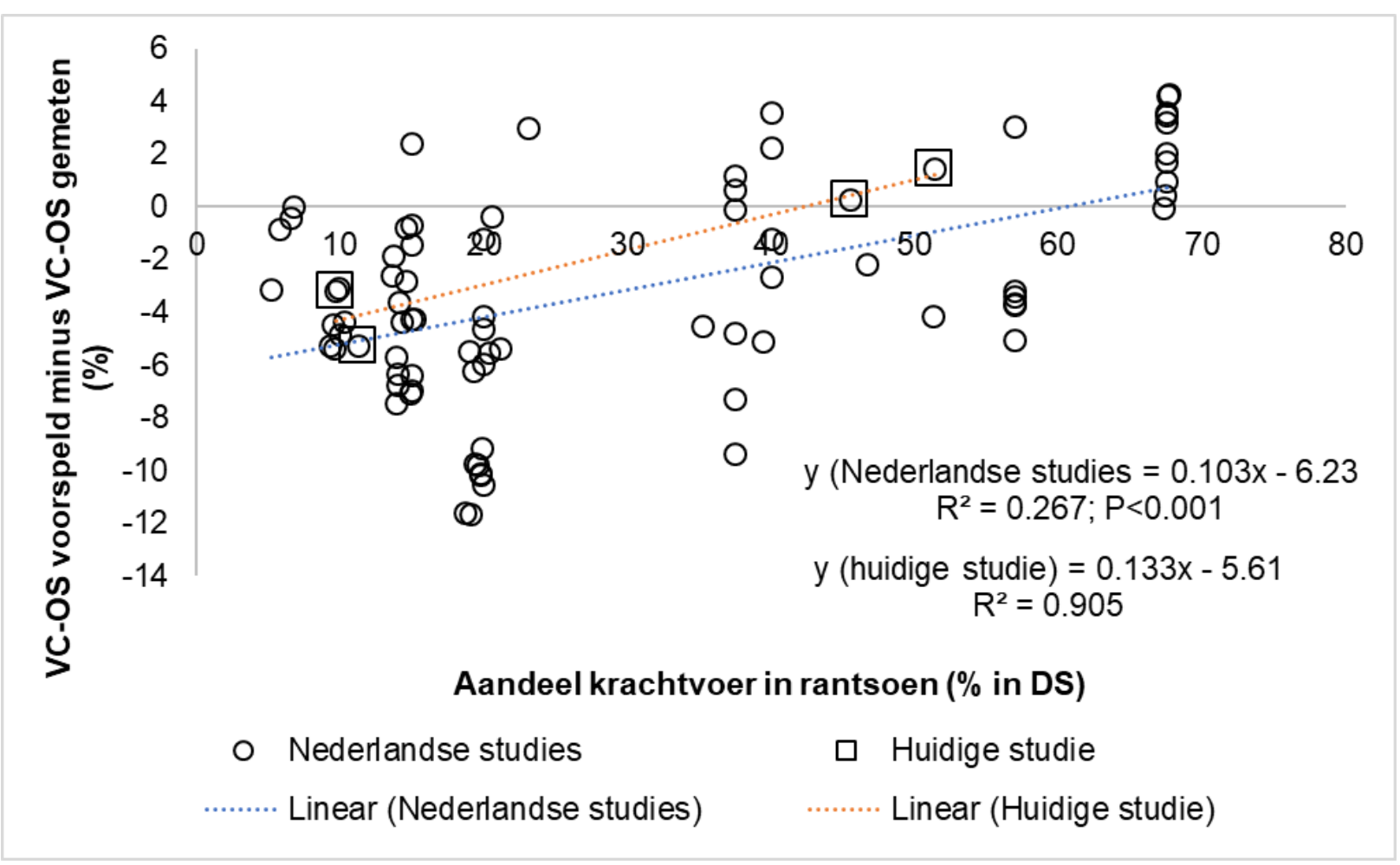

Figuur 2 Relatie tussen VC-OS voorspeld (\% o.b.v. hamelverteerbaarheden en gecorrigeerd voor voeropname niveau) minus VC-OS (\%) gemeten in Nederlandse verteringsstuddies en het aandeel krachtvoer in het rantsoen uitgedrukt als \% in de droge stof.

\subsection{ME benutting voor melkproductie en energiebehoefte voor onderhoud}

In Figuur 1 zijn de, voor mobilisatie en retentie gecorrigeerde relaties weergegeven tussen ME opname en energie output in melk. Dit is gedaan voor de gehele dataset van lacterende koeien en apart voor de HP groep en de LP groep. Uit een vergelijking tussen de HP en LP relaties blijkt dat de efficiëntie waarmee ME uit voer wordt omgezet in melk, de $B_{1}$ factor, hoger ligt bij de HP koeien dan bij de LP koeien. Het lijkt erop dat hoogproductieve koeien efficiënter zijn in het omzetten van energie uit ME naar melk dan laagproductieve koeien. Verder blijkt uit deze zelfde relaties dat de geschatte energiebehoefte voor onderhoud hoger is voor hoogproductieve dieren dan voor laagproductieve dieren. Deze observaties passen in het beeld van andere studies (Fig. 3). Mogelijke (combinaties van) verklaringen voor deze sterke correlatie tussen $\mathrm{NE}_{\text {ond }}$ (of $\mathrm{B}_{0}$ ) en $\mathrm{K}_{\mathrm{l}}$ (of $\mathrm{B}_{1}$ ) zijn:

1. Dat deze twee parameters sterk met elkaar verstrengeld zijn.

2. Dat hoogproductieve koeien efficiënter omgaan met dezelfde (type) energie dan laagproductieve koeien maar tegelijkertijd ook een hogere energiebehoefte voor onderhoud hebben.

3. Dat hoogproductieve koeien een ander type rantsoen krijgen (meer vet en zetmeel) dan laagproductieve dieren en dat conversie van metabool beschikbaar vet en zetmeel naar melkenergie hoger ligt dan voor vezel. Dit gecombineerd met het feit dat hoogproductieve dieren tegelijkertijd ook een hogere energiebehoefte voor onderhoud hebben. 


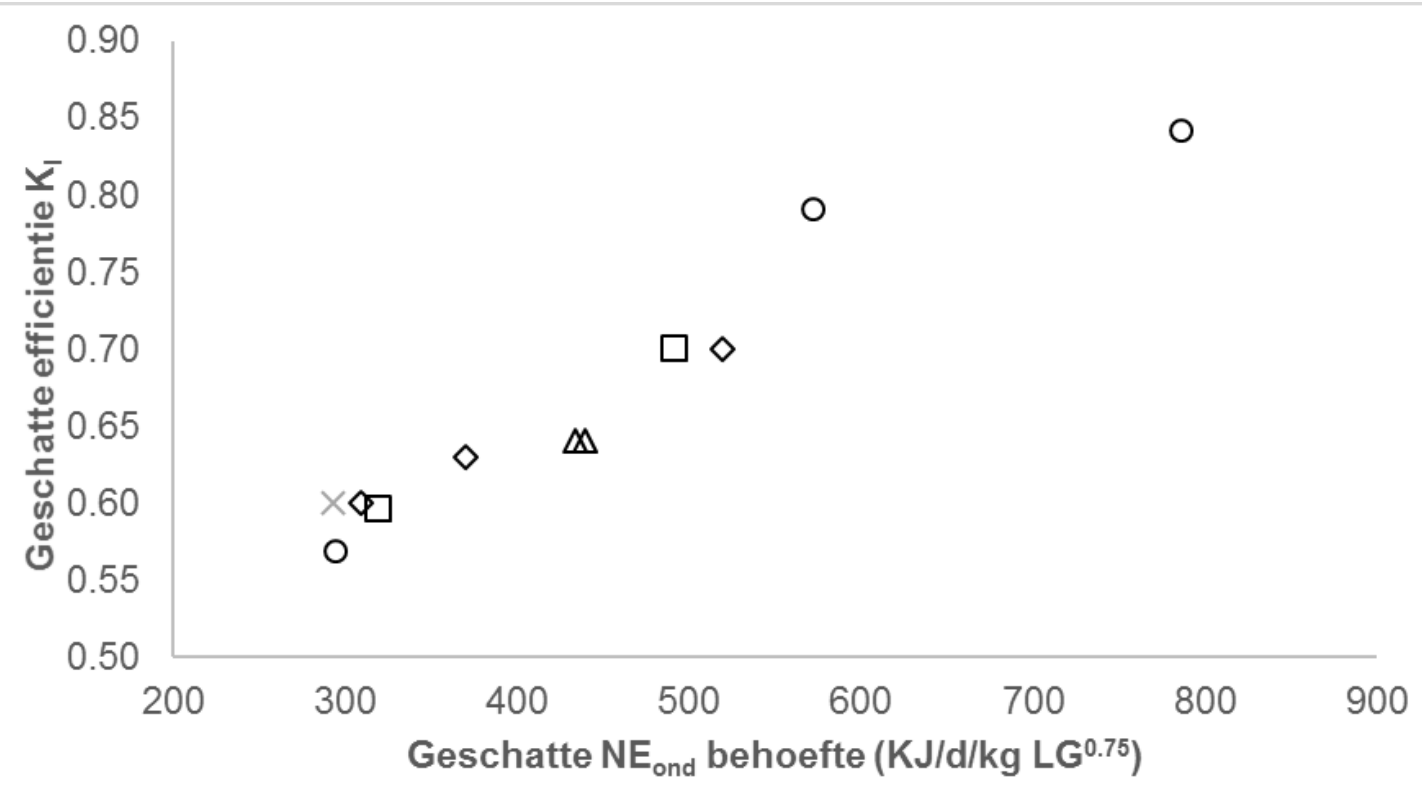

口Deze studie

$\diamond$ Moraes et al (2015) $\quad \times$ Van Es (1975)

$\Delta$ Dong et al. (2015) OBruinenberg et al. (2002)

Figuur 3 Relatie tussen de geschatte efficiëntie waarmee ME uit voer wordt omgezet in melkenergie $\left(K_{l}\right)$ en de geschatte netto energie behoefte voor onderhoud ( $N E_{\text {ond }}: \mathrm{KJ} / \mathrm{d} / \mathrm{kg}$ $L G^{0.75}$ ) voor de huidige studie en voor andere studies uitgevoerd in klimaatrespiratiekamers.

\subsection{Energiemetabolisme}

Om de resultaten van de KRC metingen te vergelijken met resultaten van andere proeven is gekeken naar de relatie tussen ME opname en warmteproductie en tussen ME opname en methaanemissie. Ter vergelijking zijn recente resultaten uit studies van Hatew et al. (2015, 2016), Van Gastelen et al. (2018) en Warner et al. (2015) meegenomen. Deze studies zijn uitgevoerd met de doelstelling om methaanemissie te verlagen. Behandelingen bestonden uit verschillen in droge stofgehalten van maiskuil (Hatew et al. 2016), stikstofbemesting en groeiduur bij vers gras (Warner et al. 2015), stikstofbemesting en groeiduur bij kuilgras (Warner et al. 2015), zetmeelgehalte en fermentatiesnelheid van zetmeel (Hatew et al. 2015) en toevoeging van lijnzaad olie (Van Gastelen et al. 2018). In Figuur 4 is de relatie weergegeven tussen fecaal verteerbare energieopname en warmteproductie. Bij een visuele analyse van Fig. 4 lijkt het erop dat de warmteproductie in de huidige proef hoger ligt dan de gemiddelde warmteproductie van de proeven uit de methaanemissiestudies. Een verklaring hiervoor is het feit dat koeien in de HP behandelingen gemiddeld een negatieve energiebalans hadden en lichaamsenergie mobiliseerden waarbij ook warmte vrijkomt terwijl in de proeven uit de methaanemissiestudies koeien gemiddeld gezien een positieve energiebalans hadden (gemiddeld $72 \pm 74 \mathrm{KJ} / \mathrm{d} / \mathrm{kg} \mathrm{LG}{ }^{0.75}$ ). Een andere mogelijke verklaring voor deze observatie is het feit dat de voeropname bij de HP behandelingen tijdens de meetperiode in de KRC ongeveer $13 \%$ lager lag dan in de voorgaande adaptatieperiode op de standenstallen en dat een deel van de warmteproductie bestaat uit een na-ijleffect van extra voer opgenomen tijdens de adaptatieperiode. Van de 12 koeien die HP behandelingen kregen bleken er 8 koeien een DSO op de $\mathrm{KRC}$ te hebben die meer dan $2.5 \mathrm{~kg}$ lager lag dan de DS opname in de laatste 4 dagen van de adaptatieperiode. De overige 4 waarnemingen hadden slechts een gemiddeld $0.77 \mathrm{~kg}$ lagere DSO op de KRC. In Figuur 5 is de relatie tussen fecaal verteerbare energieopname en warmteproductie opnieuw weergegeven maar dan zonder de 8 observaties waarvan de verschillen in DSO meer dan 2.5 $\mathrm{kg} / \mathrm{d}$ bedroegen. De resultaten in Fig. 5 laten zien dat de relatie tussen fecaal verteerbare energieopname en warmteproductie voor de literatuurdata na verwijderen van de 8 observaties van 


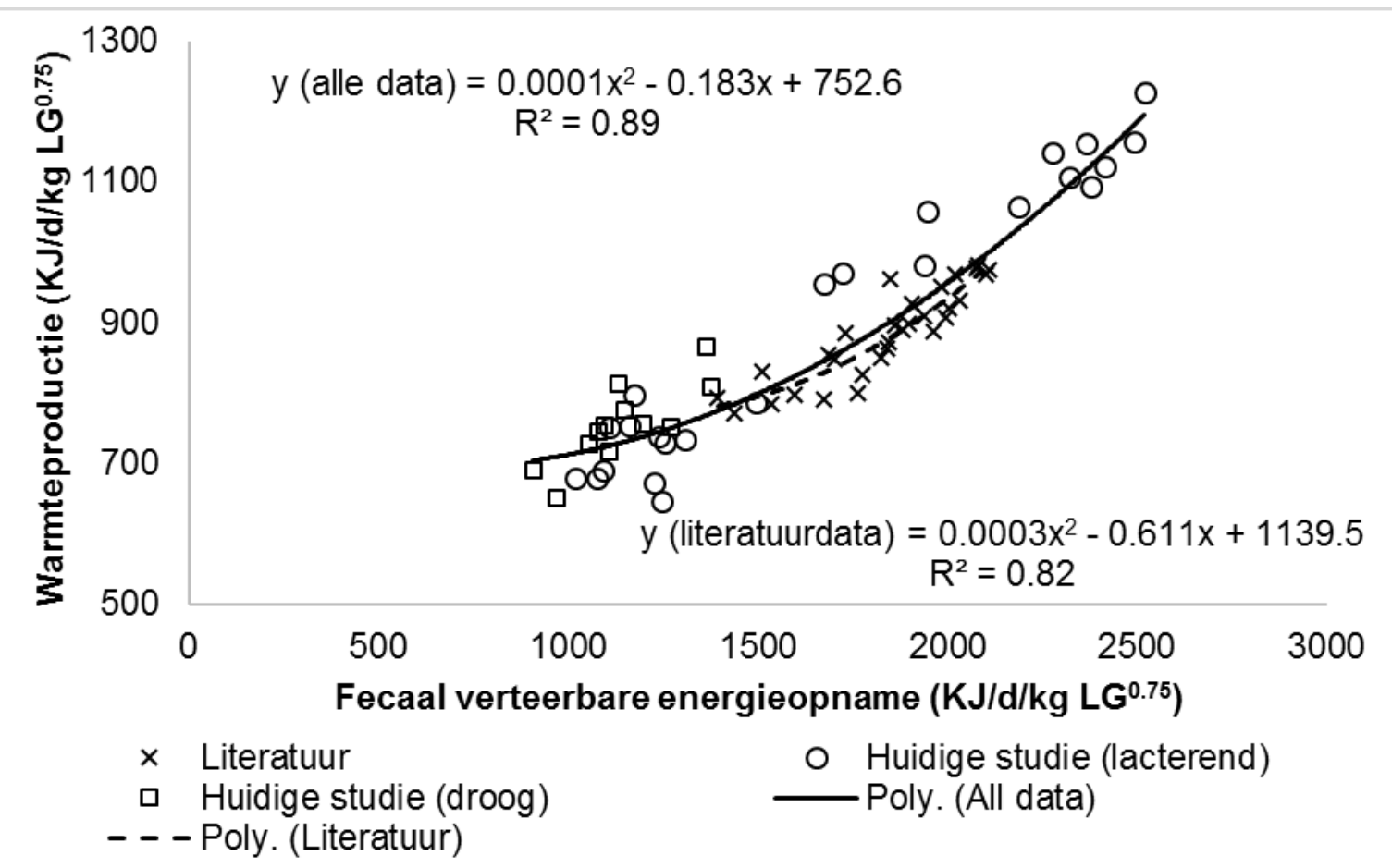

Figuur 4 Relatie tussen fecaal verteerbare energieopname (KJ/d/kg LG $\left.{ }^{0.75}\right)$ en warmteproductie $\left(\mathrm{KJ} / \mathrm{d} / \mathrm{kg} L \mathrm{G}^{0.75}\right)$ voor resultaten uit de huidige studie (individuele koedata) en van literatuurdata (behandelingsgemiddelden). De doorgetrokken regressielijn is gefit door alle data van zowel de literatuurdata als de resultaten uit de huidige studie. De onderbroken regressielijn is alleen gefit door de literatuurdata. 


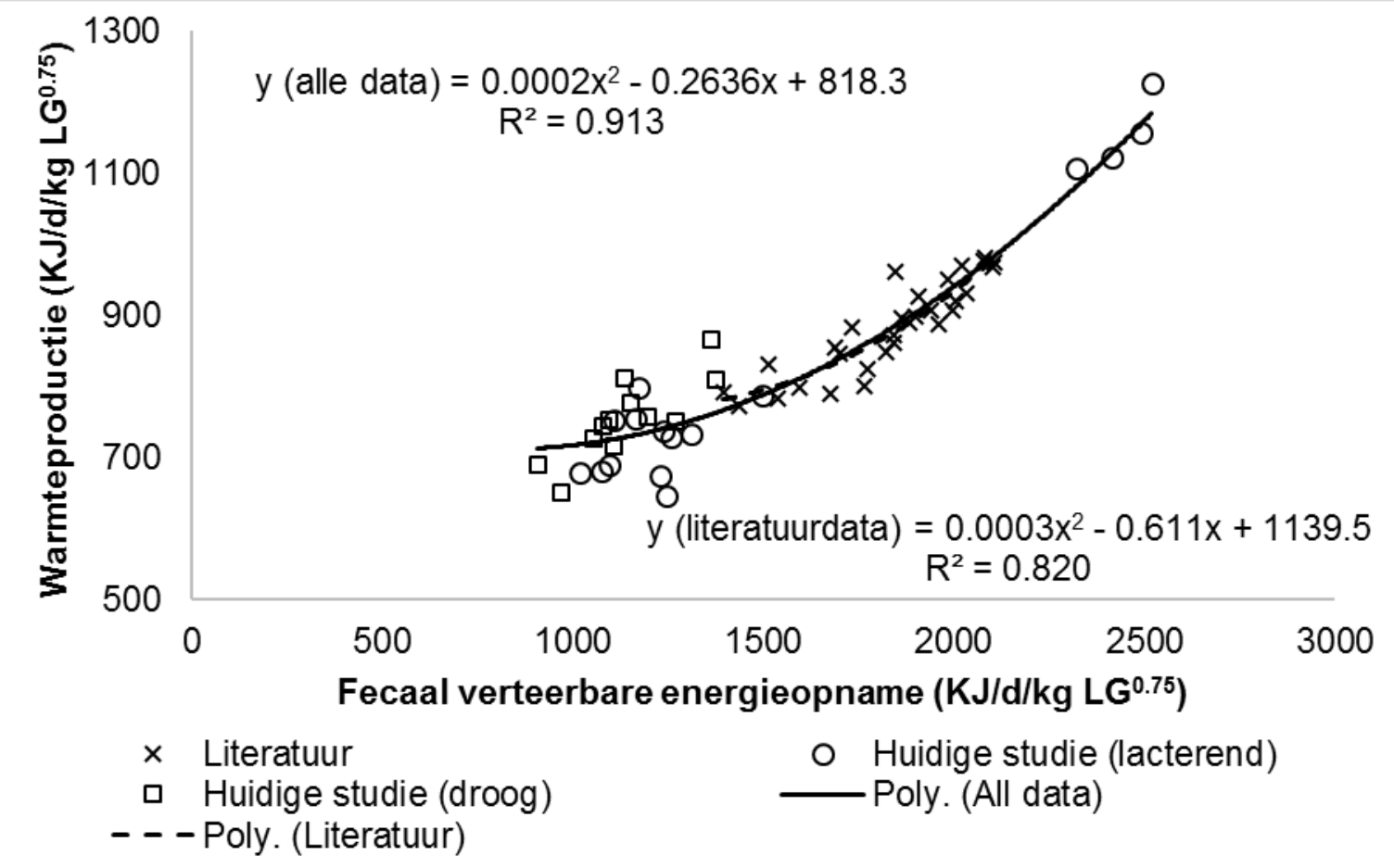

Figuur 5 Relatie tussen fecaal verteerbare energieopname (KJ/d/kg LG $\left.{ }^{0.75}\right)$ en warmteproductie $\left(\mathrm{KJ} / \mathrm{d} / \mathrm{kg} L \mathrm{G}^{0.75}\right)$ voor resultaten uit de huidige studie (individuele koedata; exclusief de data van 8 hoogproductieve koeien warvan verschillen in droge stofopname tussen adaptatieperiode en meetperiode meer dan $2.5 \mathrm{~kg} / \mathrm{d}$ bedroegen) en van literatuurdata (behandelingsgemiddelden). De doorgetrokken regressielijn is gefit door alle data van zowel de literatuurdata als de resultaten uit de huidige studie. De onderbroken regressielijn is alleen gefit door de literatuurdata.

In Figuur 6 is de relatie weergegeven tussen fecaal verteerbare energieopname en methaanproductie voor alle observaties in de huidige studie. In Figuur 7 is de relatie weergegeven tussen fecaal verteerbare energieopname en methaanproductie zonder de 8 observaties waarvan de verschillen in DSO meer dan $2.5 \mathrm{~kg} / \mathrm{d}$ bedroegen. De resultaten in zowel Fig. 6 als Fig. 7 laten zien dat de relatie tussen fecaal verteerbare energieopname en methaanproductie voor de literatuurdata goed overeenkomt met de relatie tussen fecaal verteerbare energieopname en methaanproductie voor de gecombineerde dataset van literatuurdata en data uit de huidige proef. Een visuele vergelijking tussen Fig. 6 en 7 laat ook zien dat het al of niet weglaten van de eerder genoemde 8 uitbijters weinig effect heeft op de geschatte relatie tussen fecaal verteerbare energieopname en methaanproductie. 


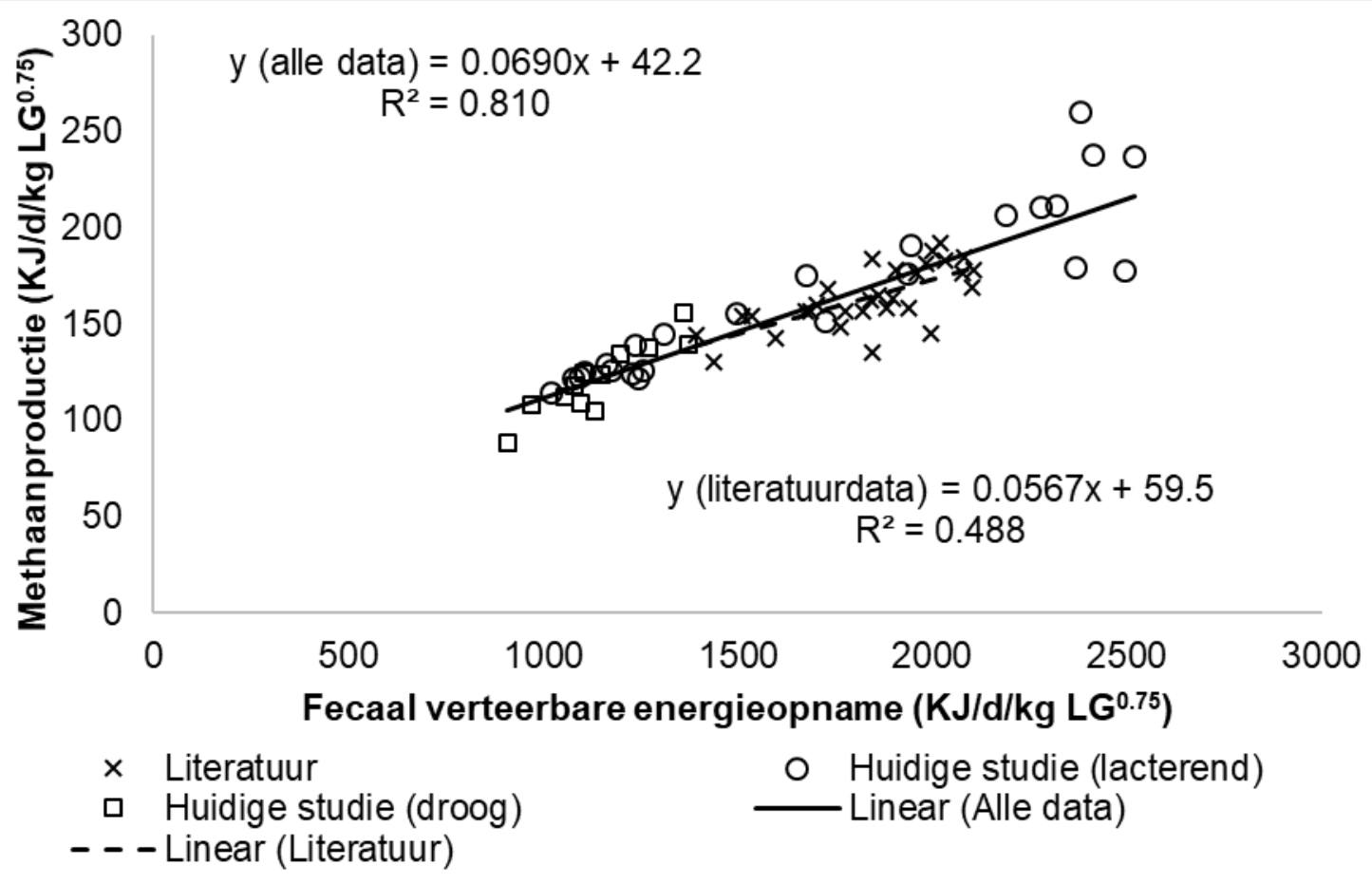

Figuur 6 Relatie tussen fecaal verteerbare energieopname ( $\left.K J / d / k g ~ L G^{0.75}\right)$ en methaanproductie $\left(\mathrm{KJ} / \mathrm{d} / \mathrm{kg} L \mathrm{G}^{0.75}\right)$ voor resultaten uit de huidige studie (individuele koedata) en van literatuurdata (behandelingsgemiddelden). De doorgetrokken regressielijn is gefit door alle data van zowel de literatuurdata als de resultaten uit de huidige studie. De onderbroken regressielijn is alleen gefit door de literatuurdata. 


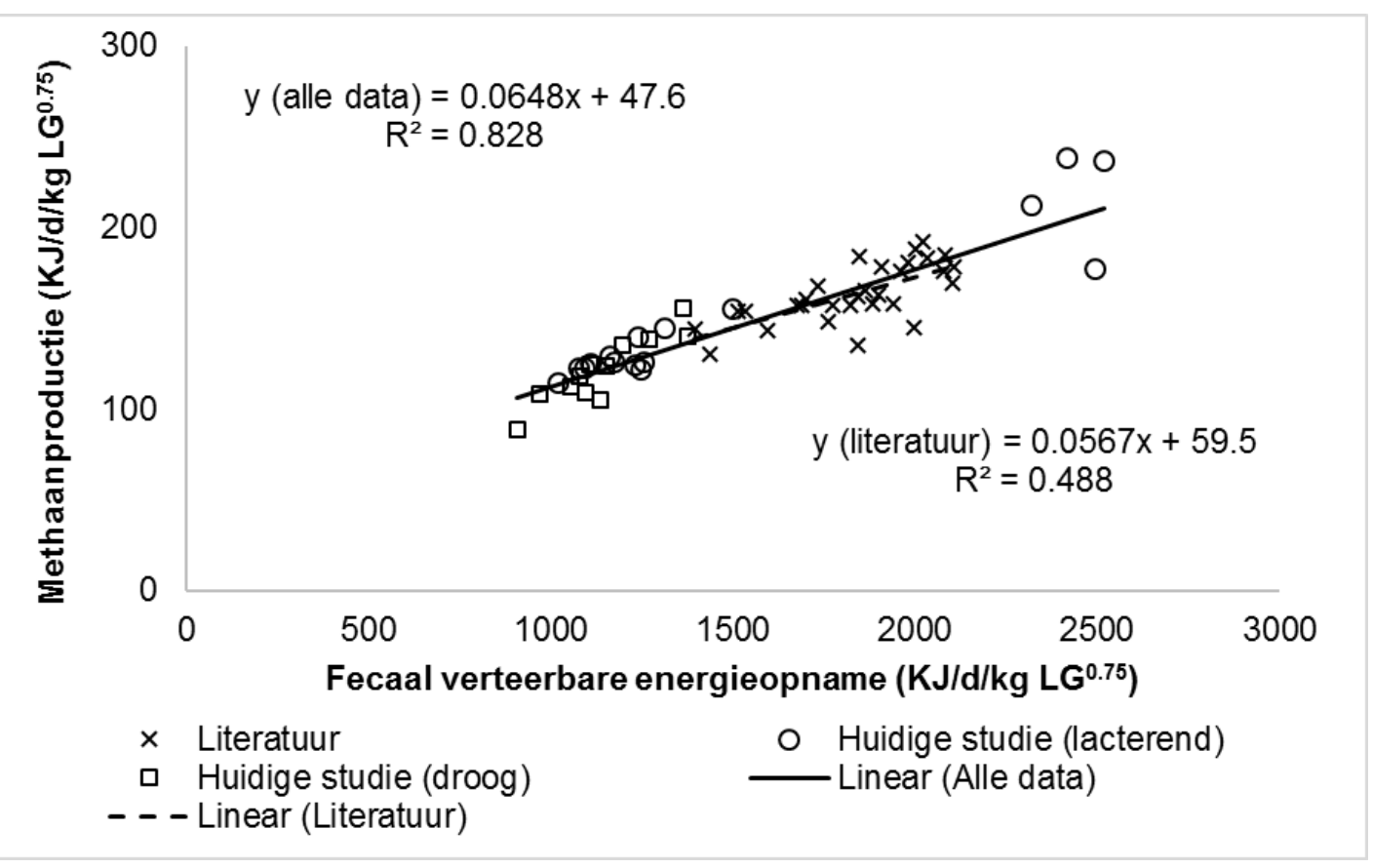

Figurr 7 Relatie tussen fecaal verteerbare energieopname ( $\left.\mathrm{KJ} / \mathrm{d} / \mathrm{kg} L \mathrm{G}^{0.75}\right)$ en methaanproductie $\left(\mathrm{KJ} / \mathrm{d} / \mathrm{kg} \mathrm{LG}^{0.75}\right)$ voor resultaten uit de huidige studie (individuele koedata; exclusief de data van 8 hoogproductieve koeien waarvan verschillen in droge stofopname tussen adaptatieperiode en meetperiode meer dan $2.5 \mathrm{~kg} / \mathrm{d}$ bedroegen) en van literatuurdata (behandelingsgemiddelden). De doorgetrokken regressielijn is gefit door alle data van zowel de literatuurdata als de resultaten uit de huidige studie. De onderbroken regressielijn is alleen gefit door de literatuurdata.

In Tabel 9 zijn de dezelfde modellen doorgerekend als in Tabel 6 maar dan gebaseerd op de dataset exclusief de 8 observaties waarvan de verschillen in DSO tussen de laatste 4 dagen van de adaptatieperiode en de meetperiode in de cellen meer dan $2.5 \mathrm{~kg} / \mathrm{d}$ bedroegen. Uit een vergelijking tussen de resultaten in Tabel 6 en Tabel 9 blijkt dat voor model 2 de verschillen in modelschatting bijzonder klein zijn. Wanneer voor model 2 in Tabel 9 de VEM behoefte voor onderhoud wordt berekend blijkt dit te resulteren in een toename t.o.v. de huidige VEM behoefte van $15.2 \%$.

Tabel 9 Geschatte modelparameters voor het schatten van de energie excretie in melk $\left(\left(k J / d / L G^{0.75} / d\right)\right.$ die zijn geschat op de dataset na verwijderen van de 8 observaties waarvan de verschillen in DSO tussen de laatste 4 dagen van de adaptatieperiode en de meetperiode in de cellen meer dan $2.5 \mathrm{~kg} / \mathrm{d}$ bedroegen.*

\begin{tabular}{|c|c|c|c|c|c|c|}
\hline \multicolumn{7}{|c|}{ Modelparameters** } \\
\hline & Bo & $\mathbf{B}_{1}$ & $\mathbf{B}_{\mathbf{2}}$ & $\mathrm{B}_{3}$ & RMSE & $\mathbf{R}^{2}$ \\
\hline Model 1 & $-332 \pm 31.1$ & $0.617 \pm 0.0222$ & - & - & 46.9 & 0.983 \\
\hline Model 2 & $-361 \pm 28.9$ & $0.642 \pm 0.0211$ & 0.70 & 0.89 & 44.3 & 0.985 \\
\hline
\end{tabular}

* Uitgevoerd op de dataset zonder droogstaande dieren en zonder de 8 observaties waarvan de verschillen in DSO tussen de laatste 4 dagen van de adaptatieperiode en de meetperiode in de cellen meer dan $2.5 \mathrm{~kg} / \mathrm{d}$ bedroegen ( $\mathrm{n}=16$ ).

** De parameters $\mathrm{B}_{2}$ en $\mathrm{B}_{3}$ zijn niet door het model geschat maar als harde waarden in het model ingevuld waarbij de waarden zijn gebaseerd op schattingen gepresenteerd in de studie van Moraes et al. (2015).

$B_{0}=$ de interceptwaarde en gelijk aan de geschatte netto energie behoefte voor onderhoud $\times-1\left(N E_{o n d}\left(\left(K^{\prime} / d / k g ~ L G .75\right)\right)\right.$. De metaboliseerbare energiebehoefte voor onderhoud $\left(\mathrm{ME}_{\text {ond }}\left(\mathrm{KJ} / \mathrm{d} / \mathrm{kg} \mathrm{LG}^{0.75}\right)\right.$ ) kan berekend worden als $-\mathrm{B}_{0} / \mathrm{B}_{1}$.

$B_{1}=$ de efficiëntie waarmee ME uit voer wordt omgezet in melkenergie.

$B_{2}=$ de efficiëntie waarmee ME uit voer wordt omgezet in lichaamsenergie (voornamelijk vet)

$B_{3}=$ de efficiëntie waarmee lichaamsenergie (voornamelijk vet) wordt omgezet in melkenergie.

In Tabel 10 zijn de dezelfde energie- en stikstofbalansgegevens weergegeven voor de HP behandelingen als in Tabel 5 maar dan gebaseerd op de dataset exclusief de 8 observaties waarvan de verschillen in DSO tussen de laatste 4 dagen van de adaptatieperiode en de meetperiode in de cellen 
meer dan $2.5 \mathrm{~kg} / \mathrm{d}$ bedroegen. Uit een vergelijking tussen de resultaten in Tabel 5 en Tabel 10 blijkt dat de resultaten van de energie- en stikstofbalans er na verwijderen van de 8 observaties behoorlijk te veranderen. Zo is er nu bijvoorbeeld sprake van een positieve netto energieretentie terwijl deze eerst negatief was. De schijnbare fecale verteerbaarheden van nutriënten worden iets lager t.o.v. de volledige dataset.

Tabel 10 Stikstof- en energiebalans en schijnbare fecale verteerbaarheden van nutriënten voor de HP behandelingen exclusief de 8 observaties waarvan de verschillen in DSO tussen de laatste 4 dagen van de adaptatieperiode en de meetperiode in de cellen meer dan 2.5 $\mathrm{kg} / \mathrm{d}$ bedroegen.

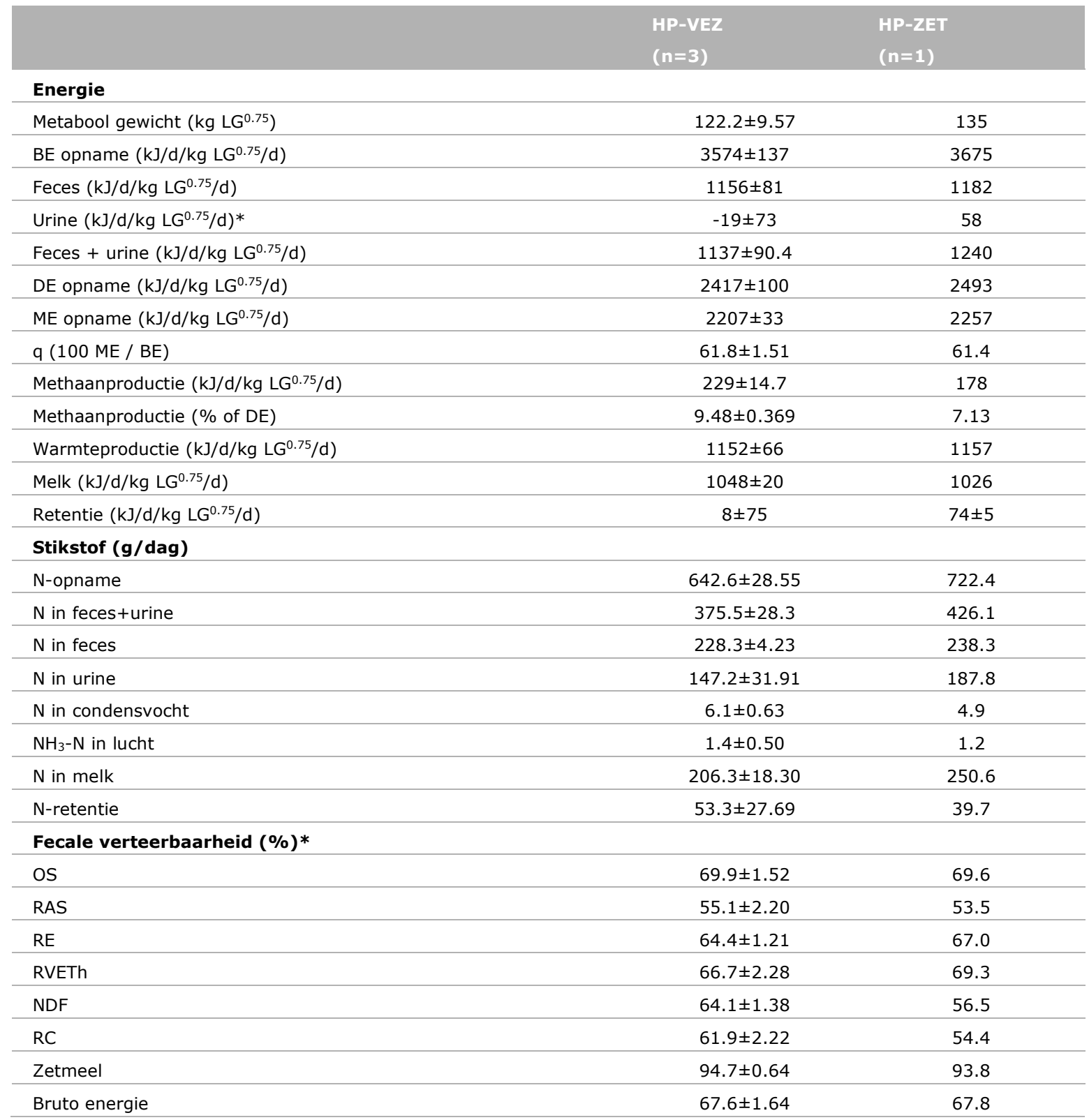

* OS, organische stof; RAS, ruw as; RE, ruw eiwit; RVETh, ruw vet na zure hydrolyse; NDF, neutral detergent fibre; RC, ruwe celstof.

Concluderend kan gezegd worden dat het al of niet weglaten van de 8 observaties waarvan de verschillen in DSO tussen de laatste 4 dagen van de adaptatieperiode en de meetperiode in de cellen meer dan $2.5 \mathrm{~kg} / \mathrm{d}$ bedroegen weinig of geen effect heeft op de geschatte energiebehoefte voor onderhoud. Daarom is ervoor gekozen om deze 8 observaties meet te nemen in het schatten van de energiebehoefte voor onderhoud en deze 8 observaties dus niet als uitbijters te beschouwen. 


\subsection{Verschil tussen energie in mest en mest + urine}

Opvallend is het kleine verschil dat soms wordt waargenomen tussen de hoeveelheid energie in mest en in mest+urine, waarbij er in twee gevallen een negatieve energie excretie in de urine werd berekend van -63.6 en $-59.1 \mathrm{KJ} / \mathrm{d} / \mathrm{kg} \mathrm{LG}{ }^{0.75}$. Deze twee koeien kregen beide een HP-VEZ rantsoen. Wanneer deze twee waarnemingen werden weggelaten dan resulteerde dit in een gemiddelde energie excretie voor de HP-VEZ behandeling van $32 \pm 23.4 \mathrm{KJ} / \mathrm{d} / \mathrm{kg} \mathrm{LG} \mathrm{LG}^{0.75}$. Het is onduidelijk waarom deze twee dieren een negatieve berekende energie excretie in urine hadden en er zijn verschillende verklaringen om deze negatieve waarden te verklaren. Dit kan bijvoorbeeld verklaard worden door een fout in de bepaling van de energie excretie in feces en in mest. Bij één van de twee dieren met een negatieve berekende energie excretie in urine werd een lage fecale energieverteerbaarheid van $65.9 \%$ gevonden (laagste verteerbaarheid van de betreffende behandeling) terwijl de gemiddelde verteerbaarheid van de betreffende behandeling op $68.4 \%$ lag. Een andere verklaring is dat er een fout is gemaakt in het schatten van de hoeveelheid geproduceerde mest. Zo leidt een onderschatting van het droge stofgehalte tot een onderschatting van de energie excretie in de mest, wat weer kan leiden tot een negatieve berekende energie excretie in urine. Bij één van de twee dieren met een negatieve berekende energie excretie in urine werd een laag droge stofgehalte van de mest (feces + urine) gevonden van $38.4 \mathrm{~g} / \mathrm{kg}$ (laagste droge stofgehalte van de betreffend behandeling) terwijl het gemiddelde droge stofgehalte $43.9 \mathrm{~g} / \mathrm{kg}$ bedroeg.

Vanwege de hogere excretie van stikstof in de urine van de HP behandelingen in vergelijking met de LP behandelingen werd ook een hogere berekende energie excretie in de urine verwacht van de HP behandelingen. Dit bleek echter niet het geval. Een vergelijking van de relatie tussen de berekende stikstof uitscheiding in de urine en de berekende energie excretie in urine van deze studie met andere studies (Fig. 8) laat zien dat de berekende energie excreties in urine binnen de variatie vallen die gevonden is in andere studies. Concluderend blijft het onduidelijk waarom er bij twee koeien een negatieve berekende energie excretie in urine is vastgesteld. Dit is fysiologisch onmogelijk en laat zien dat er ergens meet/analyse onnauwkeurigheden zitten. Dat dit niet alleen in deze studie het geval is maar ook voorkomt in ander studies blijkt uit Fig. 8 en dan met name uit de studie van Warner et al. (2017).

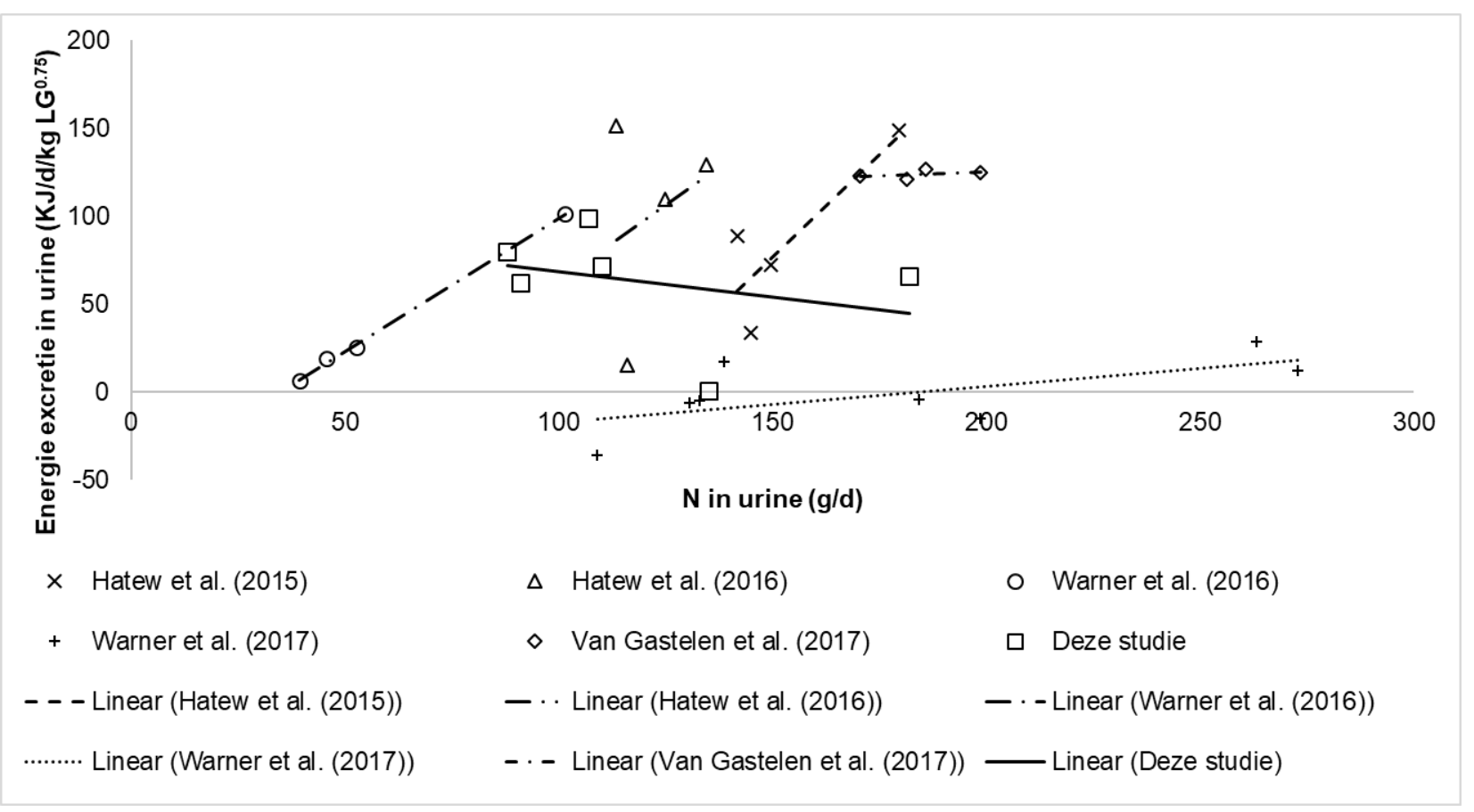

Figuur 8 Relatie tussen stikstofuitscheiding in urine $(\mathrm{N} \mathrm{g} / \mathrm{d})$ en de berekende energie-excretie in urine $\left(\mathrm{KJ} / \mathrm{d} / \mathrm{kg} L \mathrm{G}^{0.75}\right)$ voor Holstein Friesian koeien in deze studie en in andere studies. 


\subsection{Verschil $\mathrm{ME}_{\text {ond }}$ tussen lacterende en droge koeien}

In deze studie werd voor zowel lacterende als droge koeien een hogere onderhoudsbehoefte berekend dan de $\mathrm{ME}_{\text {ond }}$ Van $488\left(\mathrm{KJ} / \mathrm{d} / \mathrm{kg} \mathrm{LG}^{0.75}\right)$ die nu wordt gebruikt in het Nederlandse VEM systeem. Een hogere onderhoudsbehoefte werd ook verwacht op basis van recent uitgevoerde studies (Agnew et al. 2003: Dong et al. 2015: Moraes et al. 2015) waarin voor melkgevende koeien ook hogere $\mathrm{ME}_{\text {ond }}$ waarden dan $488 \mathrm{KJ} / \mathrm{d} / \mathrm{kg} \mathrm{LG}{ }^{0.75}$ werden gevonden van respectievelijk 590, 683 en 740 (KJ/d/kg LG 0.75 voor de studies van Agnew et al. (2003), Dong et al. (2015), en Moraes et al. (2015).

Wat niet werd verwacht is dat in deze studie een hogere onderhoudsbehoefte voor onderhoud voor droogstaande dieren is gevonden dan voor de lacterende dieren. De berekende $\mathrm{ME}_{\text {ond }}$ van droge koeien was gemiddeld $676\left(\mathrm{KJ} / \mathrm{d} / \mathrm{kg} \mathrm{LG}^{0.75}\right.$ ) (Tabel 7) en de geëxtrapoleerde MEond van lacterende koeien was gemiddeld $566\left(\mathrm{KJ} / \mathrm{d} / \mathrm{kg} \mathrm{LG}{ }^{0.75}\right.$ ) (Tabel 9). De hypothese was dat juist de lacterende dieren een hogere onderhoudsbehoefte zouden hebben vanwege een groter aandeel aan organen (verteringsorganen en uier) die veel energie verbruiken per $\mathrm{kg}$ lichaamsgewicht. Eén verklaring kan zijn dat melkgevende dieren een efficiëntere energiehuishouding hebben dan droogstaande dieren. Zo rapporteerde Moe (1981) dat de efficiëntie waarmee ME werd vastgezet in lichaamsweefsel $75 \%$ was bij melkgevende koeien en slechts $60 \%$ bij droogstaande koeien. Een tweede verklaring voor de hogere gemeten energiebehoefte voor droogstaande dieren in deze studie is het feit dat deze dieren een positieve energiebalans hadden en mogelijk naast vet ook eiwit hebben aangezet. Een indicatie dat dit heeft plaatsgevonden is het feit dat de berekende stikstofretentie bij de droogstaande dieren een stuk hoger lag dan bij de laagproductieve lacterende dieren. Het aanzetten van eiwit in het lichaam gebeurd met een lage energetische efficiëntie in vergelijk met het aanzetten van vet. Zo vond (Strathe et al. 2010) na statistische analyse van een dataset met respiratiegegevens van groeiende varkens dat de conversie van ME naar lichaamseiwit plaatsvond met een efficiëntie van $57 \%$ en de conversie van ME naar lichaamsvet plaatsvind met een efficiëntie van $84 \%$.

De in deze studie gebruikte efficiëntiefactor van 0.70 waarmee ME is vastgelegd in het lichaam is dan ook mogelijk te hoog. Hoe deze efficiënties bij Holstein koeien liggen is echter onduidelijk en er is weinig bekend. Als alternatief kan $\mathrm{ME}_{\text {ond }}$ voor droge koeien geschat worden aan de hand van de regressierelatie tussen Ret en ME. Op die manier wordt de gecombineerde efficiëntie waarmee vet en eiwit samen worden aangezet geschat bij droogstaande koeien en hoeven er geen aannames gemaakt te worden m.b.t. de efficiëntie waarmee ME wordt omgezet in lichaamsvet en in lichaamseiwit. Deze relatie voor de 12 dieren in deze studie is als volgt:

Ret $\left(\mathrm{KJ} / \mathrm{d} / \mathrm{kg} \mathrm{LG}{ }^{0.75}\right)=-347 \pm 114+0.565 \pm 0.1217 \times \mathrm{ME}\left(\mathrm{KJ} / \mathrm{d} / \mathrm{kg} \mathrm{LG}^{0.75}\right), \mathrm{RMSE}=39.8, \mathrm{R}^{2}=0.683$

Uit deze regressieformule blijkt dat de $\mathrm{ME}_{\text {ond }}$ voor droogstaande koeien in deze studie $347 / 0.565=$ $614\left(\mathrm{KJ} / \mathrm{d} / \mathrm{kg} \mathrm{LG}{ }^{0.75}\right)$ bedraagt. Verder kan uit deze regressieformule worden afgeleid dat ME uit voer met een efficiëntie van $56.5 \%$ wordt vastgelegd in lichaamsenergie.

Deze efficiëntie van $56.5 \%$ komt goed overeen met de geschatte efficiëntie van $60 \%$ voor droogstaande koeien door Moe et al. (1980). Geconcludeerd wordt dat de op deze alternatieve manier geschatte $\mathrm{ME}_{\text {ond }}$ voor droogstaande koeien van $614\left(\mathrm{KJ} / \mathrm{d} / \mathrm{kg} \mathrm{LG}{ }^{0.75}\right)$ een meer nauwkeurige schatting is dan de schatting gebaseerd op de aanname dat ME uit voer wordt vastgelegd in lichaamsenergie met een efficiëntie van $70 \%$. 


\section{$5 \quad$ Conclusies}

In deze studie is de metaboliseerbare energiebehoefte voor onderhoud $\left(\mathrm{ME}_{\mathrm{ond}}\right)$ voor lacterende en droogstaande Holstein Friesian koeien uitgerekend op basis van data van experimenten in klimaatrespiratiecellen $(\mathrm{KRC})$, waarbij de $\mathrm{ME}_{\text {ond }}=566 \mathrm{KJ} / \mathrm{d} / \mathrm{kg} \mathrm{LG}^{0.75}$ voor lacterende koeien en ME $\mathrm{Mn}_{\mathrm{o}}$ $=614 \mathrm{KJ} / \mathrm{d} / \mathrm{kg} \mathrm{LG} \mathrm{LG}^{0.75}$ voor droge koeien.

Op basis van deze studie wordt geconcludeerd dat:

1. De $M E_{\text {ond }}$ behoefte voor droge koeien $8 \%$ hoger is dan voor lacterende koeien

2. De huidig aangehouden MEond behoefte voor melkkoeien in het VEM systeem respectievelijk $14 \%$ en $21 \%$ te laag is voor de moderne lacterende en droge Holstein Friesian melkkoe.

3. De efficiëntie waarmee metaboliseerbare energie wordt omgezet in lichaamsenergie $57 \%$ is bij droge koeien en dat deze efficiëntie waarschijnlijk substantieel lager is in vergelijking met lacterende koeien.

Vervolg:

Om de berekende $\mathrm{ME}_{\text {ond }}$ voldoende robuust te maken om op basis daarvan de $\mathrm{ME}_{\text {ond }}$ in het huidige VEM-systeem aan te passen wordt de dataset met individuele koewaarnemingen van deze studie in een vervolgstudie gecombineerd met individuele koewaarnemingen uit eerder recent uitgevoerd WUR onderzoek met klimaatrespiratieproeven. Dit kan leiden tot aanpassingen van de schattingen uit deze studie voor de energiebehoefte voor onderhoud voor lacterende koeien en de efficiëntie waarmee metaboliseerbare energie wordt omgezet in melkenergie. 


\section{Literatuur}

Aarts, H.F.M.; Haan, M.H.A. de; Schroder, J.J.; Holster, H.C.; Boer, J.A. de; Reijs, Joan; Oenema, J.; Hilhorst, G.J.; Sebek, L.B.; Verhoeven, F.P.M.; Meerkerk, B. 2015. Grassland and forages in high output dairy farming systems. - Wageningen : Wageningen Academic Publishers (Grassland Science in Europe ) - ISBN 9789090289618 - p. 377 - 380.

Bruinenberg, M.H., Y. van der Honing, R.E. Agnew, T. Yan, A.M. van Vuuren, and H. Valk. 2002. Energy metabolism of dairy cows fed on grass. Livest. Prod. Sci. 75:117-128.

Colucci, P. E., L. E. Chase, and P. J. Van Soest. 1982. Feed intake, apparent diet digestibility, and rate of particulate passage in dairy cattle. J. Dairy Sci. 65:1445-1456.

Dong, L. F., T. Yan, C. P. Ferris, and D. A. McDowell. 2015. Comparison of maintenance energy requirement and energetic efficiency between lactating Holstein-Friesian and other groups of dairy cows. J. Dairy Sci. 98:1136-1144.

Gerrits, W. J. J., J. J. G. C. van den Borne, and E. Labussière. 2015. Deriving heat production from gaseous exchange: validity of the approach. Pages 19-34 in Indirect Calorimetry. Techniques, Computations and Applications. W. J. J. Gerrits and E. Labussière, ed. Wageningen Academic Publishers, Wageningen, the Netherlands.

Hatew, B., A. Bannink, H. van Laar, L. H. de Jonge, and J. Dijkstra. 2016. Increasing harvest maturity of whole-plant corn silage reduces methane emission of lactating dairy cows. J. Dairy Sci. 99:354-368.

Hatew, B., S. C. Podesta, H. Van Laar, W. F. Pellikaan, J. L. Ellis, J. Dijkstra, and A. Bannink. 2015. Effects of dietary starch content and rate of fermentation on methane production in lactating dairy cows. J. Dairy Sci. 98:486-499.

Hoffmann, L., R. Schiemann, W. Jentsch and G. Henseler. 1974. Die Verwertung der Futterenergie für die Milchproduktion, Archiv für Tierernaehrung, 24:3, 245-261.

Holter, J. B. 1976. Fasting Heat Production in "Lactating" Versus Dry Dairy Cows1. J. Dairy Sci. 59:755-759.

ISO 9831, 1998. Animal Feeding stuffs, animal products, and faeces or urine - Determination of gross calorific value - Bomb calorimeter method.

ISO 6496, 1999. Animal Feeding stuff - Determination of moisture and other volatile matter content, International organization for standardization, Geneve, Switzerland.

ISO 6492, 1999. Animal Feeding stuff - Determination of fat content, International organization for standardization, Geneve, Switzerland.

ISO 6865, 2000. Animal Feeding stuff _ Determination of crude fibre content - method with intermediate filtration, International organization for standardization, Geneve, Switzerland.

ISO 5984, 2002. Animal Feeding stuff - Determination of crude ash, International organization for standarization, Geneve, Switzerland.

ISO 15914, 2004. Animal Feeding stuff - Enzymatic determination of total starch content, International organization for standardization, Geneve, Switzerland.

ISO 5983, 2005. Animal Feeding stuff - Determination of nitrogen content and calculation of crude protein content - Part 1 Kjeldahl method, International organization for standardization, Geneve, Switzerland.

ISO 9622, 2013. Milk and liquid milk products. Guidelines for the application of mid-infrared spectrometry. International organization for standardization, Geneve, Switserland.

Moe, P. W. 1981. Energy Metabolism of Dairy Cattle. J. Dairy Sci. 64:1120-1139.

Moraes, L. E., E. Kebreab, A. B. Strathe, J. Dijkstra, J. France, D. P. Casper, and J. G. Fadel. 2015. Multivariate and univariate analysis of energy balance data from lactating dairy cows. J. Dairy Sci. 98:4012-4029.

Shaver, R. D., A. J. Nytes, L. D. Satter, and N. A. Jorgensen. 1986. Influence of Amount of Feed Intake and Forage Physical Form on Digestion and Passage of Prebloom Alfalfa Hay in Dairy Cows1. J. Dairy Sci. 69:1545-1559.

Strathe, A. B., A. Danfær, A. Chwalibog, H. Sørensen, and E. Kebreab. 2010. A multivariate nonlinear mixed effects method for analyzing energy partitioning in growing pigs1. J. Animal Sci. 88:2361-2372.

Strathe, A. B., J. Dijkstra, J. France, S. Lopez, T. Yan, and E. Kebreab. 2011. A Bayesian approach to analyze energy balance data from lactating dairy cows. J. Dairy Sci. 94:2520-2531.

Van Es, A.J.H. 1975. Feed evaluation for dairy cows. Livestock Production Sci. 2:95-107. 
van Gastelen, S., M. H. P. W. Visker, J. E. Edwards, E. C. Antunes-Fernandes, K. A. Hettinga, S. J. J. Alferink, W. H. Hendriks, H. Bovenhuis, H. Smidt, and J. Dijkstra. 2017. Linseed oil and DGAT1 K232A polymorphism: Effects on methane emission, energy and nitrogen metabolism, lactation performance, ruminal fermentation, and rumen microbial composition of Holstein-Friesian cows. J. Dairy Sci. 100:8939-8957.

Van Vuuren, A.M., Van der Koelen, C.J.,Valk, H., de Visser, H, 1993. Effects of partial replacement of ryegrass by low protein feeds on rumen fermentation and nitrogen loss by dairy cows. J. Dairy. Sci. 76:2982-2993.

Warner, D., B. Hatew, S. C. Podesta, G. Klop, S. Van Gastelen, H. Van Laar, J. Dijkstra, and A. Bannink. 2016. Effects of nitrogen fertilisation rate and maturity of grass silage on methane emission by lactating dairy cows. Animal 10:34-43.

Warner, D., S. C. Podesta, B. Hatew, G. Klop, H. van Laar, A. Bannink, and J. Dijkstra. 2015. Effect of nitrogen fertilization rate and regrowth interval of grass herbage on methane emission of zerograzing lactating dairy cows. J. Dairy Sci. 98:3383-3393. 

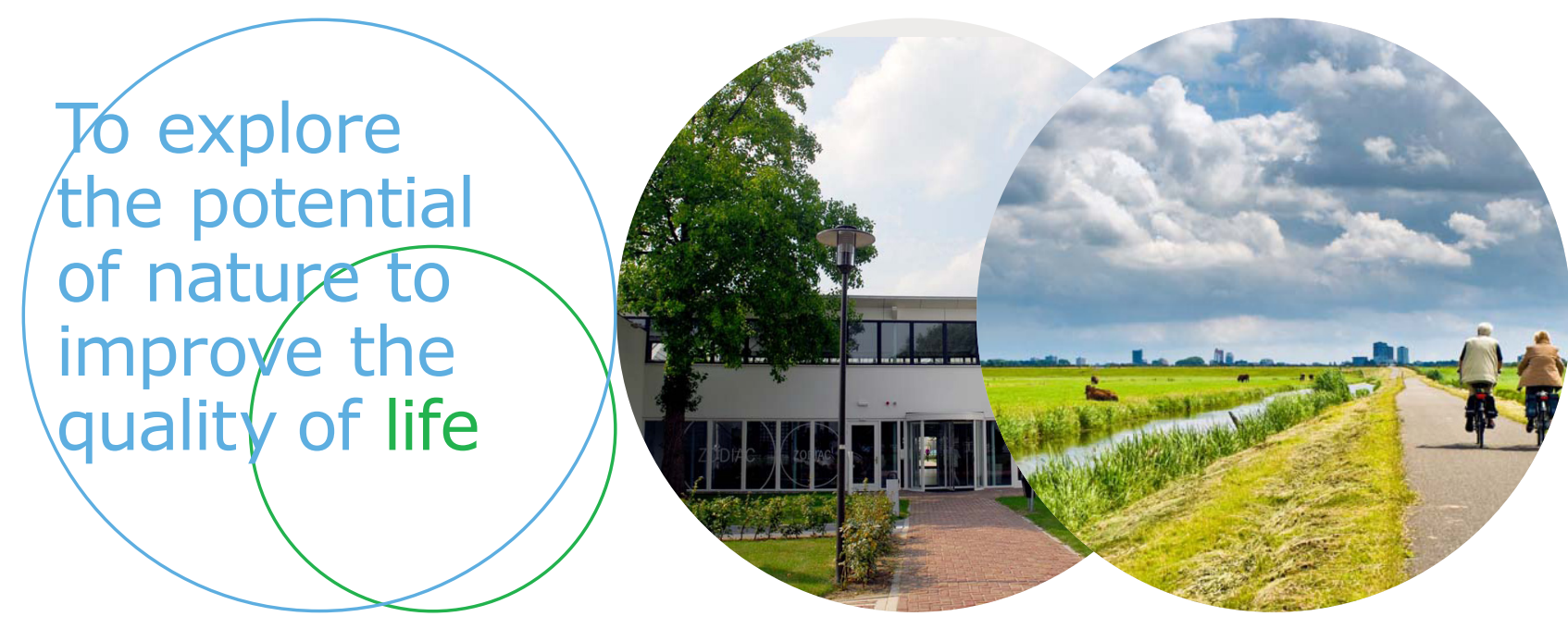

Wageningen Livestock Research Postbus 338

Wageningen Livestock Research ontwikkelt kennis voor een zorgvuldige en $6700 \mathrm{AH}$ Wageningen

T 0317483953

renderende veehouderij, vertaalt deze naar praktijkgerichte oplossingen en innovaties, en zorgt voor doorstroming van deze kennis. Onze wetenschappelijke E info.livestockresearch@wur.nl www.wur.nl/ livestock-research kennis op het gebied van veehouderijsystemen en van voeding, genetica, welzijn en milieu-impact van landbouwhuisdieren integreren we, samen met onze klanten, tot veehouderijconcepten voor de 21 e eeuw.

De missie van Wageningen University \& Research is 'To explore the potential of nature to improve the quality of life'. Binnen Wageningen University \& Research bundelen 9 gespecialiseerde onderzoeksinstituten van Stichting Wageningen Research en Wageningen University hun krachten om bij te dragen aan de oplossing van belangrijke vragen in het domein van gezonde voeding en leefomgeving. Met ongeveer 30 vestigingen, 6.500 medewerkers en 10.000 studenten behoort Wageningen University \& Research wereldwijd tot de aansprekende kennisinstellingen binnen haar domein. De integrale benadering van de vraagstukken en de samenwerking tussen verschillende disciplines vormen het hart van de unieke Wageningen aanpak. 